\title{
Why joint conservation and development projects often fail: An in-depth examination in the Peruvian Amazon
}

\begin{abstract}
Conservation projects commonly claim to convert local people into long-term environmental stewards and improve their wellbeing. Yet, evidence frequently contradicts these win-win claims. The "multiple environmentalities" framework outlines distinct approaches that projects often use to foster environmental motivation and behavior: (1) neoliberal: constructing material incentives; (2) sovereign: imposing protective laws; (3) disciplinary: fostering norms and values. We use a mixed method approach to examine how combinations of these environmentalities shape the land use motivations and behavior of 270 families living in 15 project settings in the Peruvian Amazon. We identify four direct reasons why these projects often fail to achieve their intended outcomes, regardless of the environmentalities employed: (1) self-selection of like-minded individuals; (2) limited ability of extrinsic motivators (i.e. material incentives and protective laws) to reduce reported deforestation behaviors; (3) limited internalization of motivations for conservation; (4) ignored broader economic drivers of deforestation. We argue that these challenges stem from the typical external design of conservation projects, based on fixed and limited interpretations of human motivation. Our findings point to the importance of deliberative processes that can support local and external actors to navigate and reframe competing motivations to co-design approaches to conservation governance at local and broader scales.
\end{abstract}

\section{Highlights}

- Conservation projects in northern Peru commonly combine neoliberal, sovereign and disciplinary environmentalities, with neoliberal environmentality the most widespread.

- Projects tended to attract like-minded actors, rarely internalized intrinsic motivations, and ignored broader economic drivers, hindering long-term conservation outcomes.

- Extrinsic motivations were poorly linked to environmental behavior, as many resisted restrictions and used project incentives for their own aims.

- Limited success of conservation projects stems from their external design based on a narrow understanding of human motivation and behavior.

- Local deliberative processes may help navigate the multi-faceted nature of people's motivations to strengthen local conservation governance. 


\section{Introduction}

Diverse approaches are used to conserve nature in local settings around the world. Several strategies have become particularly prevalent worldwide, including protected areas, community-based regimes, and market-based approaches (Borgerhoff Mulder \& Coppolillo 2005; Roe 2008; Büscher \& Fletcher 2015). Projects based on one or more of these strategies often promise multiple local and global scale benefits, such as to conserve biodiversity, maintain watersheds, preserve cultural values, reduce poverty, meet global food demands and mitigate climate change (Muradian et al. 2013; Roe et al. 2003). The spread of these initiatives has outpaced the critical assessment of their impacts, with serious deficiencies and growing concerns regarding our understanding of how they shape local conservation and human well-being outcomes (Roe et al. 2015; McShane et al. 2011; Sunderland et al. 2008; Agrawal \& Redford 2006). This has led to heated debates in recent years over whether or not to give nature monetary value to conserve it (Kallis et al. 2013), and whether or not to support the topdown protection of nature versus more integrated participatory approaches (Büscher et al. 2017).

This paper sheds light on these debates by taking an in-depth look at how distinct conservation and development strategies interact with the heterogeneous motivations of people living in project areas to shape their land use motivations and behaviors. We employ the "multiple environmentalities" framework (see Fletcher 2010) to guide our investigation, which outlines distinct ways of motivating conservation behavior, such as through offering incentives (i.e. neoliberal), imposing enforcement (i.e. sovereign), or internalizing new norms and values (i.e. disciplinary). The emerging literature that applies this framework has explained how and why conservation projects often produce contradictory and unintended outcomes in specific project settings (Youdelis 2013; Bluwstein 2017; Valladares \& Boelens 2019). To our knowledge, we provide the first study that systematically examines the full process of how and why different combinations of these environmentalities and other factors shape reported deforestation motivations and behaviors of diverse individuals living in multiple project sites in northern Peru. Our explanation of the most proximate reasons why win-win conservation projects often fail generates important practical insights for how interventions can foster long-term environmental commitment. We also offer theoretical insights that inform how interacting environmentalities are conceptualized and their role in advancing these practical efforts.

To elaborate these insights, we first begin with an overview of the key theoretical distinctions that the multiple environmentalities framework entails. We then reflect on some key concerns and debates raised across the literature regarding the implications of these intersecting approaches before proceeding with our analysis in the context of the San Martin Region in northern Peru. Our findings highlight some major reasons why joint conservation and development projects often fail, paving the 
way for our discussion of how projects could possibly be done differently, and the potential role of a reconceptualized environmentalities theory to inform this effort.

\section{Multiple environmentalities to motivate conservation}

The "multiple environmentalities" framework introduced by Fletcher (2010) draws upon Foucault's (2008) multiple governmentalities theory to explain distinct ways that interventions attempt to influence subjects to produce environmental behavior. The focus is on how interventions seek to "discipline" people to think, speak and act in particular ways to achieve their objectives (Foucault 1980, 1994). Three distinct environmentalities outlined include: (1) neoliberal: "manipulation of external incentive structures", (2) sovereign: "top-down creation and enforcement of regulations", and (3) disciplinary: "encouraging internalization of norms and values" (Fletcher 2010 p. 178). These environmentalities are based on divergent assumptions regarding the major problem limiting conservation success, and thus necessary solution to motivate the desired behavior change (Figure 1). These problem-solution frames are rooted in contrasting views of human motivation; for example, people can be seen as primarily "rational" self-interested actors most responsive to sticks and/or carrots or "moral" self-disciplined actors capable of leading conservation governance. However, these approaches are not mutually exclusive; indeed, projects often combine environmentalities, assuming complementary effects (Fletcher 2017). We proceed by describing these three environmentalities and some key assumptions related to how they are employed alone or in combination (see Figure 2).

A neoliberal environmentality approach to conservation embraces the growing trend in conservation of increasing nature's economic value to incentivize its conservation (Fletcher 2010; McAfee 1999). This approach views people as primarily driven by "rational" economic and individualistic concerns (Douglas 1978). Poverty is therefore often framed as a "critical constraint on conservation" (Adams et al. 2004 p. 1147), making income generation key to conservation success. Several mechanisms fall under this banner, such as integrated conservation and development projects (Blom et al. 2010), sustainable agricultural intensification (Tilman et al. 2011), ecological certifications (Blackman \& Rivera 2010), and voluntary payments for ecosystem services (PES) schemes (Farley \& Costanza 2010). These mechanisms range from the sole production of benefits to reduce people's economic need to deforest (Figure 2; approach $\mathrm{N}$ ), to integrating environmental messages, such as through community-based ecotourism or PES schemes (Figure 2; approach ND). The former assumes that material benefits alone can incentivize conservation, while the latter assumes that people must jointly learn about the importance of the environment in order to "crowd in" (i.e. internalize) values that may outlive the incentives (see Frey \& Jegen 2001). 
A sovereign environmentality approach to conservation is widespread globally through the creation and enforcement of protected areas (Fletcher 2010). This approach (Figure 2; approach S) explicitly prioritizes conservation over development aims, a position embodied in the "nature needs half" discourse (Wilson 2016) and the idea that nature must be safeguarded from local people (Redford 1991; Oates 1995). However, growing recognition of the negative social impacts of protected areas and the idea that local people's support may be critical for achieving conservation has produced a more socially sensitive variant. Such projects first secure conservation through hierarchical authority (Douglas 1970, 1978), and then employ neoliberal environmentality to compensate local people for costs borne from restrictions and to incentivize compliance (Brockington \& Igoe 2006; Adams \& Hutton 2007) (Figure 2; approach SN). This effort may be driven by a concern for social equity - that conservation should do no harm to the poor - and/or may be seen as an efficient means to conservation if poverty is seen as the root cause of environmental degradation (Karsenty et al. 2017).

While the environmentalities discussed thus far rely on extrinsic structures to change behavior and therefore inherently assume that conservation is not in local people's self-interest, the disciplinary environmentality approach (Figure 2; approach D) instead views conservation as being important for local people. This is because poverty reduction is seen as dependent on conserving natural resources (Adams et al. 2004) and also often because people are seen to be capable of recognizing the intrinsic importance of nature. The widespread community-based natural resource management (CBNRM) movement embraces this assumption that interventions can instill biospheric and altruistic knowledge and values (see Stern et al. 1993) in order to promote conservation (Agrawal 2005). Such projects also commonly seek to create and enforce governance regimes to regulate people's use of natural resources, such as through community forest guardians (i.e. Figure 2; approach SD).

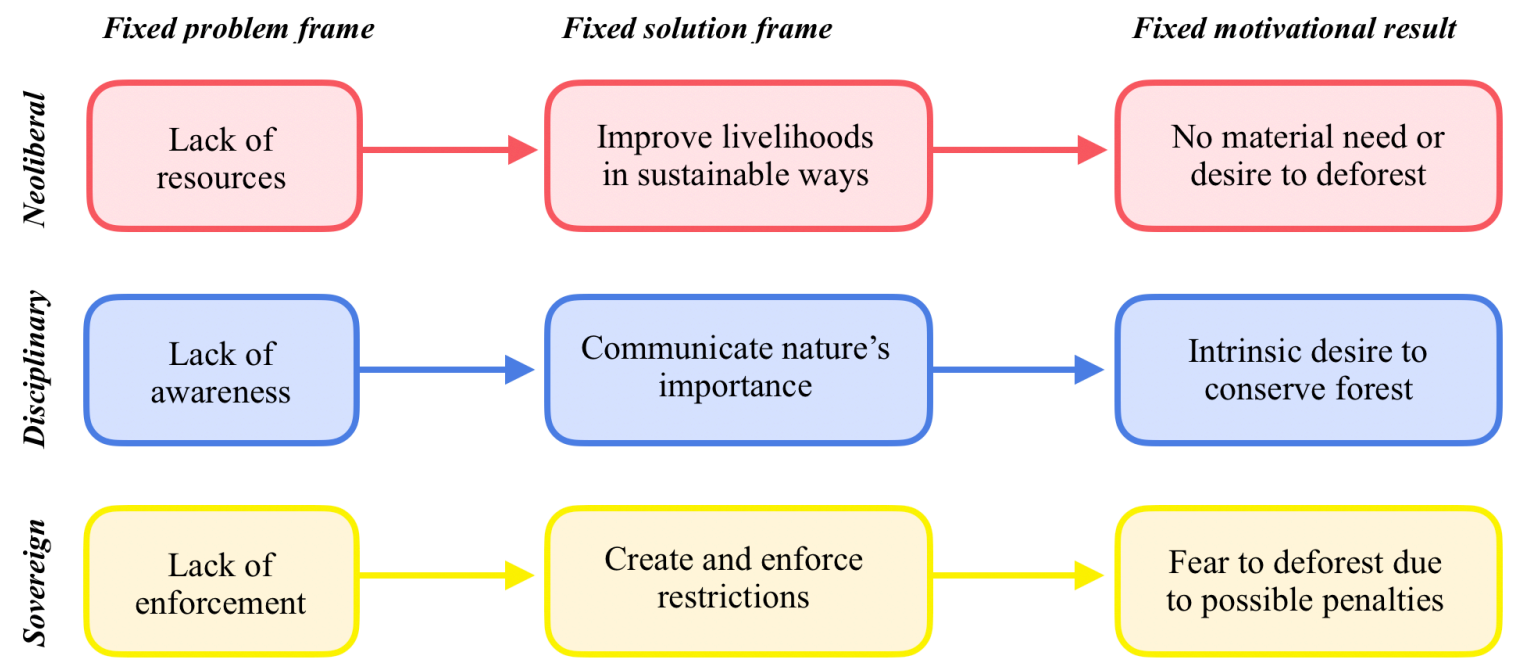

Figure 1. Fixed assumptions of each environmentality regarding the main problem to address, solution offered, and motivational result that creates environmental subjects. 


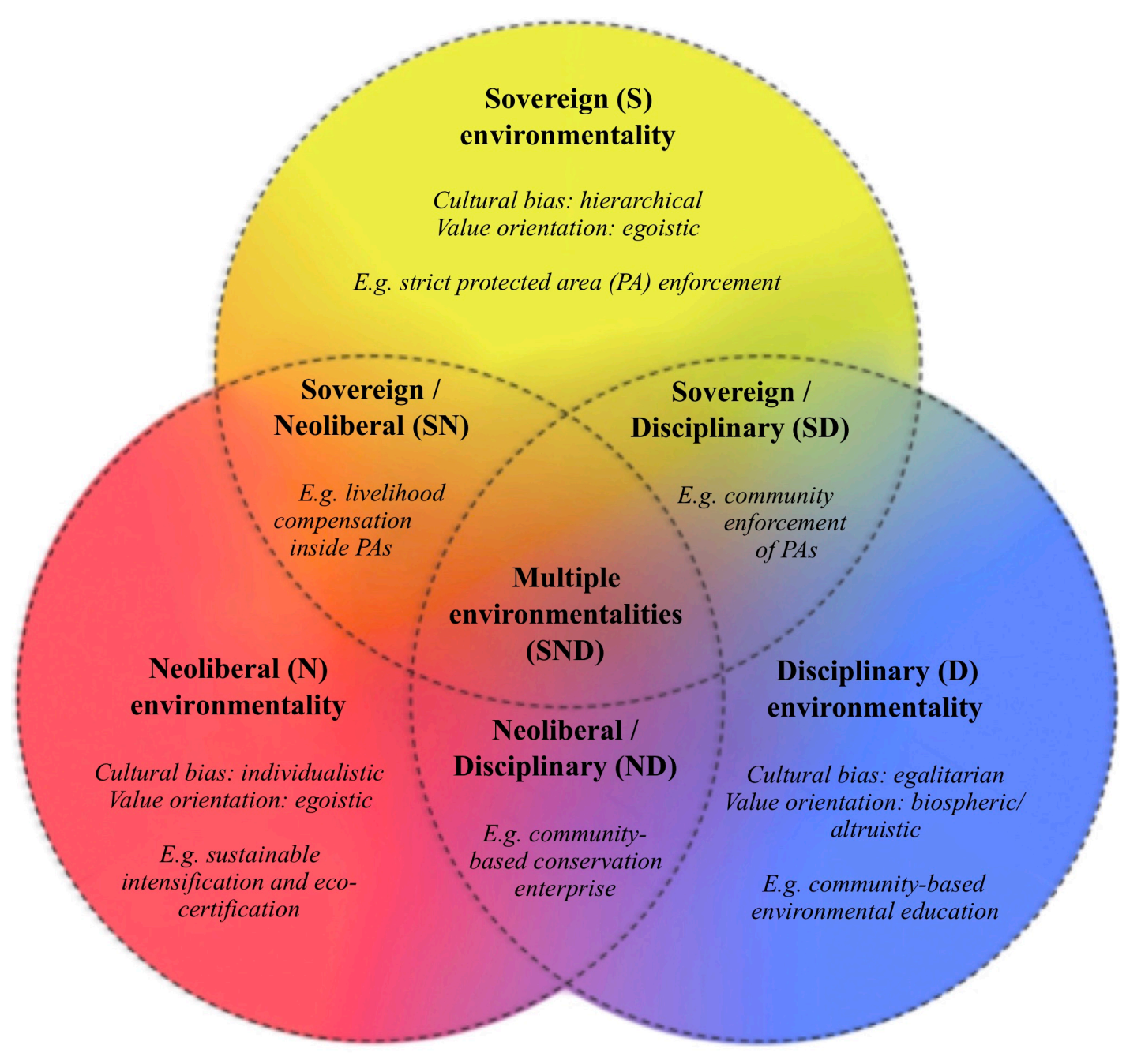

Figure 2. Conceptual map of overlapping approaches to conservation (informed by Fletcher 2010; Stern et al. 1993; Douglas 1978)

Neoliberal, sovereign and disciplinary environmentalities are rarely employed in isolation, but instead frequently combined in practice (Fletcher 2017). For example, protected area regimes may jointly employ material incentives and/or environmental education (Figure 2; approach SND), with the assumption that these approaches are naturally complementary to enhance project success. Similarly, efforts to catalyze community conservation may involve the development of new income sources and efforts to create and enforce use restrictions. Despite many implicit assumptions regarding the effects of these distinct approaches and how they interact to shape local people's motivations for conservation, they are rarely systematically studied (Fletcher 2017). Several recent papers have emphasized the need to better understand the causal mechanisms by which intervention approaches shape people's motivations and behaviors in particular ways (ibid; Börner et al. 2016; Miteva et al. 2012; Rode et al. 2015). We proceed with a brief overview of existing literature on the potential conservation implications of these environmentalities before moving on to our in-depth exploration of their implications in the context of forest conservation projects in the San Martin Region, Peru. 


\section{The promises and perils of distinct environmentalities}

Using the lens of multiple environmentalities but drawing upon the broader conservation impact evaluation literature, we review some evidence for the potential implications of the approaches outlined above. We do not provide an exhaustive review, but rather highlight some key concerns and debates raised to date that we seek to inform with our study.

Fierce debate has emerged surrounding the implications of a neoliberal environmentality approach to resolving conservation problems. Proponents claim that giving nature economic value can directly incentivize its conservation (Pagiola 2008; Blackman \& Naranjo 2012) and help "crowd in" long-term intrinsic motivations (Rosa et al. 2003; Wunder 2013). Others caution that this approach can: 1) perversely incentivize nature's degradation (Crook \& Clapp 2002; Belcher et al. 2005; Kusters et al. 2006; Lybbert et al. 2011); 2) shift ecologically destructive activities to other behavioral or spatial realms (Stronza 2009; Brashares et al. 2011; Madhusudan 2005); 3) exacerbate social inequalities through elite capture and resource grabbing behaviors (Corbera et al. 2007; Sommerville et al. 2010a; Pokorny et al. 2012; Fairhead et al. 2012); 4) produce limited effects that disappear when incentives do (Clough et al. 2009; Fisher 2012); 5) "crowd out" moral reasons to conserve (Rode et al. 2015) and 6) reify relatively minor behavioral shifts of poorer actors while failing to question more ecologically damaging neoliberal patterns of power and resource distribution (McAfee 1999; Büscher et al. 2012). It therefore remains unclear under what conditions material incentives can help further long-term conservation aims or may work against them.

Considering the role of sovereign environmentality, studies that have examined the effectiveness of terrestrial protected areas suggest that on average they have prevented 12\% of deforestation (Andam et al. 2008; Sims 2010; Miteva et al. 2012). Yet, high rates of deforestation and degradation persist in many protected areas with weak governance and limited funds (Curran et al. 2004; Bonham et al. 2008). Protected areas can also produce "leakage", whereby pressures from human activities are displaced elsewhere (Gan \& McCarl 2007; Ewers \& Rodrigues 2008). In some cases, enforcement mechanisms may be so effective that biodiversity objectives can be achieved amidst a disregard for social impacts (Brockington 2003). However, in many cases the social process by which restrictions are developed and enforced will heavily shape outcomes (West et al. 2006; Lele et al. 2010). Despite increasing efforts to improve livelihoods in protected areas, benefits have often failed to provide socially acceptable compensation for negative impacts such as constrained resource access and forced evictions, making protected areas significant sites of conflict and struggle (Adams \& Hutton 2007; Baker et al. 2013). It therefore remains unclear how creating and enforcing rules can play a productive role in conservation efforts, as opposed to hindering outcomes by alienating potential local allies. 
The implications of disciplinary environmentality for fostering collective concern for conservation have been examined in the community based natural resource management (CBNRM) literature, with numerous success stories reported (Ostrom \& Nagendra 2006; Kilbane Gockel \& Gray 2009; Chhatre \& Agrawal 2009; Persha et al. 2011). However, the causal mechanisms remain unclear given the typical self-selection bias of participating communities and wide diversity regarding what CBNRM means in practice (Lele et al. 2010; Bowler et al. 2012; Miteva et al. 2012). For example, early community-based management models, such as integrated conservation and development projects (ICDPs), were more focused on generating revenue (i.e. neoliberal environmentality) than enhancing the awareness, rights and governance capacity of communities (Dressler et al. 2010). Systematic reviews show some evidence for improved social outcomes; however conservation success has been limited, and joint success across both dimensions is rare (Dressler et al. 2010; Lele et al. 2010; Bowler et al. 2012; Samii et al. 2014). These failures have led some to demand renewed attention to protected areas (Hutton et al. 2005; Wilson 2016). Other perspectives show that community driven efforts can be successful amidst strong democratic governance, state recognition, long-term facilitation and equitable benefit-sharing (Haller et al. 2018; Brooks 2016; Tole 2010; Waylen et al. 2010). There is still limited understanding of how people come to embrace environmental values and norms.

We aim to contribute to all of these ongoing debates by providing the most systematic study to date of how these three environmentalities that underpin common conservation strategies worldwide shape the motivations of diverse local actors in northern Peru. Past studies have assessed the outcomes of one or more interventions in particular contexts (e.g. Ellis \& Porter-Bolland 2008; Sommerville et al. 2010b; Ferraro et al. 2013). The broader impact evaluation literature has often focused on individual policy instruments (such as PES or protected areas), across numerous contexts, without recognizing how these models often employ different mixtures of regulatory, economic and/or informational strategies in practice (Barton et al. 2017). The emerging environmentalities literature has examined these components in specific project contexts using primarily qualitative methodologies. We apply a mixed method approach to investigate the detailed ways combinations of these environmentalities shape individual motivations and behaviors across 15 project sites in northern Peru.

Our findings explain how and why people often respond to these strategies in unintended ways to limit project success. We demonstrate that the improvement of projects is not so much a matter of what law, incentive or message will work best, but rather how the competing motivations of internal and external actors are facilitated to interact and reshape each other. In doing so, we challenge the focus of the environmentalities framework on analyzing the implementation of strategies (Cf. Cepek 2011; Cortes-Vazquez \& Ruiz-Ballesteros 2018), and argue its potential lies in how it can help identify and negotiate competing motivations to co-design conservation governance initiatives. These 
insights are timely given how widespread these strategies are among projects in northern Peru and worldwide, and ongoing concerns regarding their impacts (Börner et al. 2016; Fletcher 2017).

\section{Background: A landscape of environmentalities}

\section{Overview of research area}

The San Martin Region provides an ideal setting for this research, as it is home to a diverse array of intervention forms that combine different environmentalities. Environmental conservation first became an issue in San Martin with the construction of a major highway across the region in the 1960s. This set in motion a historical migratory pathway from the Peruvian highlands and northern coast to San Martin in pursuit of cheap land for agricultural expansion, leading to a six-fold increase in population and the loss of $26 \%$ of the region's forest cover by 2000 (MINAM 2009). Initial efforts to conserve the region's forests in the mid-1980s involved the expansion of environmental regulation and protected areas at the national scale (Zinngrebe 2016). Although protected areas in San Martin were initially poorly managed, the creation of the Regional Environmental Authority in 2010 greatly increased enforcement capacity. As a consequence, 142 people were prosecuted for deforesting a total of $\sim 900$ hectares in 2012, up from just 11 people in 2009 (FEMA-Moyobamba 2013). The steep increase in international funding for protected areas in San Martin since the late 2000s has supported the expansion of livelihood projects to compensate for negative impacts (Nakamura 2017).

A contrasting conservation strategy spread throughout the San Martin Region in response to the global community-based conservation narrative and the passing of 11 major decentralization laws in Peru during 2002 - 2004, which handed over power and funding to regional and local governments to manage their territories (Zinngrebe 2016; Martinez-Vasquez 2013). This facilitated the development of a new legal tool - "conservation concessions" - which allowed civil society groups to formally manage state-owned lands for conservation purposes. The first conservation concession in San Martin was established by a community group in 2006; over 30 concessions now exist, covering $12 \%$ of the region's territory (ARA-GORESAM 2017).

A third conservation strategy that emerged in the region of San Martin stems from the framing of the agroforestry cash crops coffee and cacao as sustainable alternatives to environmentally destructive coca and "slash-and-burn" practices in the early 2000s (UNODC 2011). Related conservation interventions have since sought to jointly increase the economic and biodiversity value of cash crop areas by incentivizing agroforestry practices, planting trees on-farm, improving productivity and developing ecologically certified value chains. In some cases, these efforts have been explicitly coupled to sparing natural habitat through voluntary conservation agreements. Over the past decade, 
international corporations seeking to voluntarily offset their carbon emissions have increasingly funded such approaches in San Martin, facilitated by the establishment of the San Martin REDD+ Roundtable in 2011 (la Mesa REDD+ San Martín 2013).

As a result of all of these efforts, San Martin is now known as the "green region" of Peru, with $72 \%$ of its remaining forest cover (encompassing $47 \%$ of the total land area) presently under some form of conservation management, increased from just $12 \%$ in 2000 (ARA-GORESAM, 2017). Yet, at the same time, deforestation rates are on the rise since 2000 (la Mesa REDD+ San Martín 2013), driven by the 3.5-fold expansion of the major cash crops of coffee, cacao and oil palm (DRASAM 2013).

\section{Overview of project sites}

The historical expansion of protected areas, community-based management regimes and cash crop incentive programs across the San Martin Region produced a diverse landscape of conservation projects that encompass various combinations of environmentalities. To examine multiple cases of interventions combining particular environmentalities, pilot interviews were conducted with 25 San Martin-based conservation project managers in 2013 to select a total of fifteen study communities (Figure 3). We included at least three sites for each combination of two environmentalities (Figure 2; approaches SN, SD and ND). Due to the much higher prevalence of projects only rooted in neoliberal environmentality (approach $\mathrm{N}$ ), we chose to also examine five examples of this category. Although these fixed boundaries are necessary to distinguish between approaches, it is important to emphasize how fluid interventions are across the conceptual space portrayed in Figure 2. We did not label any cases as equally employing all three environmentalities (i.e. approach SND), as all projects tended to favor certain environmentalities over others. The sites selected for each approach are not evenly spaced throughout the region, as people only lived inside of protected areas in the northwest, and the only projects that combined disciplinary and sovereign environmentalities were located in the east.

To examine project implications, we intentionally focused on communities that conservation organizations pointed to as "successful" examples to avoid simply documenting implementation failures, such as a failure of incentives to arrive or laws to be enforced. This no doubt directed our attention away from the effects of poor implementation and towards examples where strategies were better matched to particular contexts; however, it sharpened our analysis of the implications of the actual implementation of distinct approaches to shaping conservation motivations and behaviors. Table 1 provides an overview of the major characteristics of the conservation projects and communities examined for each approach outlined in Figure 2. Projects were categorized into these approaches based on initial interviews with intervention directors and workshops in the selected sites. 


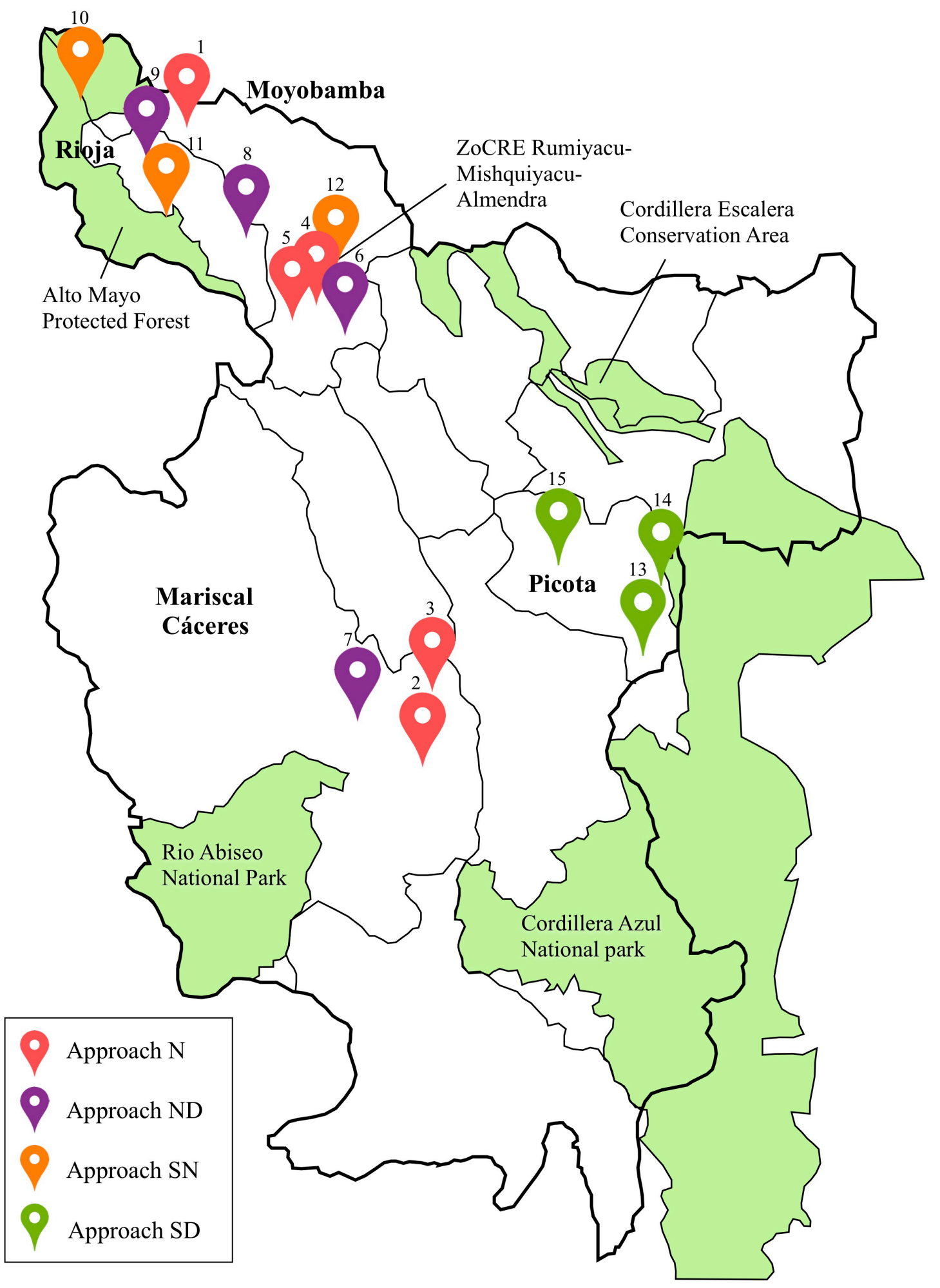

Figure 3. Location of fifteen study communities across four provinces of the San Martin Region, Peru. 
Table 1. Characteristics of conservation projects and study communities (numbers correspond with those in Figure 3).

\begin{tabular}{|c|c|c|c|c|c|c|c|}
\hline Approach & $\begin{array}{l}\text { Conservation } \\
\text { Projects }\end{array}$ & $\begin{array}{l}\text { Main proponents } \\
\text { and donors }\end{array}$ & Description & $\begin{array}{l}\text { Study } \\
\text { communities }\end{array}$ & $\begin{array}{l}\text { Community } \\
\text { size (families) }\end{array}$ & $\begin{array}{l}\text { Percent. } \\
\text { involved }\end{array}$ & $\begin{array}{l}\text { Project } \\
\text { duration }\end{array}$ \\
\hline \multirow{6}{*}{$\begin{array}{l}\text { Neoliberal } \\
\text { (N) }\end{array}$} & $\begin{array}{l}\text { CAPEMA eco- } \\
\text { certification }\end{array}$ & $\begin{array}{l}\text { CAPEMA cooperative } \\
\text { Sustainable Harvest } \\
\text { Root Capital }\end{array}$ & $\begin{array}{l}\text { Supports } 250 \text { families across two provinces to improve ecologically } \\
\text { certified coffee agroforestry yields and quality and develop livestock } \\
\text { and gardens to sustainably increase food security }\end{array}$ & $\begin{array}{l}\text { (1) San José del } \\
\text { Alto Mayo - La } \\
\text { Cruz }\end{array}$ & 234 & 18 & $\begin{array}{l}2007- \\
\text { pres. }\end{array}$ \\
\hline & \multirow{2}{*}{$\begin{array}{l}\text { ACOPAGRO } \\
\text { reforestation and } \\
\text { agroforestry project }\end{array}$} & \multirow[t]{2}{*}{$\begin{array}{l}\text { ACOPAGRO cooperative } \\
\text { PUR Projet }\end{array}$} & \multirow{2}{*}{$\begin{array}{l}\text { Supports 2,000 families across four provinces to improve ecologically } \\
\text { certified cacao agroforestry yields and quality and plant certified } \\
\text { timber trees to sustainably increase food security and store carbon }\end{array}$} & (2) Cayena & 91 & 35 & $\begin{array}{l}2004- \\
\text { pres. }\end{array}$ \\
\hline & & & & (3) Shepte & 144 & 31 & $\begin{array}{l}2000- \\
\text { pres. }\end{array}$ \\
\hline & \multirow{3}{*}{$\begin{array}{l}\text { Solidaridad Climate } \\
\text { Smart Agriculture } \\
\text { Project }\end{array}$} & \multirow{3}{*}{$\begin{array}{l}\text { Solidaridad Network } \\
\text { Norwegian Agency for } \\
\text { Development Cooperation }\end{array}$} & \multirow{3}{*}{$\begin{array}{l}\text { Supports } 1,200 \text { farmers across five provinces to improve coffee } \\
\text { agroforestry yields and quality and plant timber trees to sustainably } \\
\text { increase food security and store carbon }\end{array}$} & (4) El Lucero & 130 & 15 & $\begin{array}{l}2013- \\
\text { pres. }\end{array}$ \\
\hline & & & & (5) Villa Hermosa & 120 & 25 & \\
\hline & & & & & & & $\begin{array}{l}2013- \\
\text { pres. }\end{array}$ \\
\hline \multirow{4}{*}{$\begin{array}{l}\text { Neoliberal } \\
\text { /Disciplinary } \\
\text { (ND) }\end{array}$} & $\begin{array}{l}\text { Madre Gera PES } \\
\text { (PES-GERA) }\end{array}$ & $\begin{array}{l}\text { Amazónicos por la } \\
\text { Amazonía (AMPA) } \\
\text { Forest Trends }\end{array}$ & $\begin{array}{l}\text { Supports } 26 \text { families to improve coffee agroforestry yields and quality } \\
\text { in exchange for signing a voluntary conservation agreement in a } \\
\text { watershed }\end{array}$ & $\begin{array}{l}\text { (6) Nuevo Cutervo - } \\
\text { Valle Hermoso }\end{array}$ & 115 & 9 & $\begin{array}{l}2014- \\
\text { pres. }\end{array}$ \\
\hline & $\begin{array}{l}\text { Farmers' } \\
\text { conservation } \\
\text { association }(\mathrm{CA}) \\
\text { "Solapache" }\end{array}$ & $\begin{array}{l}\text { Fundación Amazonía } \\
\text { Viva (FUNDAVI) } \\
\text { AMPA }\end{array}$ & $\begin{array}{l}\text { Supports community conservation association members to improve } \\
\text { cacao agroforestry yields and quality, develop specialty cacao } \\
\text { products, plant timber trees and conserve a communal forest area }\end{array}$ & (7) Santa Inés & 50 & 28 & $\begin{array}{l}2013- \\
\text { pres. }\end{array}$ \\
\hline & $\begin{array}{l}\text { CA “Aguajales y } \\
\text { Renacales Rio } \\
\text { Romero" (ACARR) }\end{array}$ & $\begin{array}{l}\text { Private donor } \\
\text { Alto Mayo Special Project }\end{array}$ & $\begin{array}{l}\text { Supports community conservation association members to develop } \\
\text { productive activities such as ecotourism and conserve a forest area }\end{array}$ & $\begin{array}{l}\text { (8) Santa Elena - } \\
\text { Tambo }\end{array}$ & 76 & 21 & $\begin{array}{l}2013- \\
\text { pres. }\end{array}$ \\
\hline & $\begin{array}{l}\text { Bee-keeping CA } \\
\text { "Flor de Lirio" }\end{array}$ & $\begin{array}{l}\text { AGRO RURAL } \\
\text { Alto Mayo Special Project }\end{array}$ & $\begin{array}{l}\text { Supports community conservation association members to improve } \\
\text { coffee agroforestry yields and quality, apiculture and reforest }\end{array}$ & (9) Villa Rica & 140 & 9 & $\begin{array}{l}2002- \\
\text { pres. }\end{array}$ \\
\hline \multirow{3}{*}{$\begin{array}{l}\text { Sovereign / } \\
\text { Neoliberal } \\
\text { (SN) }\end{array}$} & \multirow[t]{2}{*}{$\begin{array}{l}\text { Alto Mayo Protected } \\
\text { Forest (AMPF) }\end{array}$} & \multirow{2}{*}{$\begin{array}{l}\text { Conservation } \\
\text { International } \\
\text { National Service of PAs } \\
\text { Walt Disney }\end{array}$} & \multirow{2}{*}{$\begin{array}{l}\text { Created a 182,000-hectare protected area (AMPF) in 1987, which has } \\
\text { been increasingly enforced since 2008; supports } 845 \text { families inside to } \\
\text { improve coffee agroforestry systems and household services in } \\
\text { exchange for signing a conservation agreement }\end{array}$} & $\begin{array}{l}\text { (10) La Esperanza - } \\
\text { El Limón }\end{array}$ & 65 & 83 & $\begin{array}{l}2008- \\
\text { pres. }\end{array}$ \\
\hline & & & & (11) Sol de Oro & 83 & 29 & $\begin{array}{l}2010- \\
\text { pres. }\end{array}$ \\
\hline & $\begin{array}{l}\text { PES in Rumiyacu, } \\
\text { Mishquiyacu, } \\
\text { Almendra (PES- } \\
\text { RMA) }\end{array}$ & $\begin{array}{l}\text { EPS Moyobamba } \\
\text { Alto Mayo Special Project } \\
\text { Regional Environmental } \\
\text { Authority (ARA) }\end{array}$ & $\begin{array}{l}\text { Enforces laws of a 2,430-hectare Regional Conservation and } \\
\text { Ecosystem Recuperation Zone (ZoCRE) since 2010; supports } 57 \\
\text { families inside to improve coffee agroforestry systems and services in } \\
\text { exchange for signing a conservation agreement }\end{array}$ & $\begin{array}{l}\text { (12) San Vicente - } \\
\text { San Andres }\end{array}$ & 85 & 47 & $\begin{array}{l}2010- \\
\text { pres. }\end{array}$ \\
\hline \multirow{2}{*}{$\begin{array}{l}\text { Sovereign / } \\
\text { Disciplinary } \\
\text { (SD) }\end{array}$} & $\begin{array}{l}\text { Cordillera Azul } \\
\text { National Park } \\
\text { FOCAL model } \\
\text { (PNCAZ) }\end{array}$ & \multirow{2}{*}{$\begin{array}{l}\text { Center for Conservation, } \\
\text { Research \& Management } \\
\text { of Natural Areas (CIMA) } \\
\text { National Service of PAs } \\
\text { Althelia Climate Fund } \\
\text { Forests of the Future } \\
\text { Association "Ojos de } \\
\text { Agua" (ABOFOA) } \\
\text { Proyecto Mono Tocón } \\
\text { AMPA }\end{array}$} & \multirow{2}{*}{$\begin{array}{l}\text { Implements the model - Strengthening Local Capacities for } \\
\text { Conservation (FOCAL) - with over } 30 \text { communities in the buffer } \\
\text { zone of a } 1,353,200 \text {-hectare national park (PNCAZ) to establish } \\
\text { norms and governance for forest conservation and improve } \\
\text { community well-being } \\
\text { Supports the formation of new community conservation associations } \\
\text { (10-30 members) to obtain rights to manage state-owned forested } \\
\text { areas for conservation purposes (conservation concessions) }\end{array}$} & (13) Alto Ponaza & 100 & 60 & $\begin{array}{l}2008- \\
\text { pres. } \\
2008- \\
\text { pres. }\end{array}$ \\
\hline & $\begin{array}{l}\text { Ecological CA } \\
\text { "Bosques de } \\
\text { Pailayco" } \\
\text { (ASBOPAI) }\end{array}$ & & & (15) Villa Nueva & 58 & 28 & $\begin{array}{l}2011 \text { - } \\
\text { pres. }\end{array}$ \\
\hline
\end{tabular}




\section{Data collection and methods}

The methods used in this study were designed to understand: (1) the main motivations and factors that shape deforestation behaviors; (2) the main implications of who does (or does not) participate in interventions; (3) how interventions employing distinct combinations of environmentalities influence people's motivations; (4) the link between these motivations and reported deforestation behaviors. We will briefly describe the combined qualitative and quantitative methods we used to examine each of these topics with families living in each of the 15 project sites, with further details available in the Supplemental Materials. Our study design sought to balance our commitment to build mutual trust and respect with community members' to listen to their in-depth perspectives with our desire to learn from diverse perspectives exposed to different conservation strategies by a range of organizations. Our design and methods piece together the process by which interventions enter communities, engage with particular actors and shape their motivations in certain ways, with behavioral implications.

\section{Selecting and interviewing households}

In each of the 15 study communities, we first held a community meeting to explain the research purpose and plans, and to request permission (details provided in Appendix A). In 15 communities where permission was granted (of 16 total requests), we then worked confidentially with leaders to categorize all families according to their level of intervention participation and socio-economic status. We then randomly selected families in each category until we identified 18 families that accepted a visit, including both conservation project participants (9) and non-participants (9), and then within each of those groupings, families of higher (3), middle (3) and lower (3) socio-economic status. Among all families selected, $81 \%$ chose to accept the visit following free, prior and informed consent.

With each of the 270 families, we employed a novel research approach that involved a day-long mixed method visit during March, 2015 - January, 2016. Our ability to quickly build trust and relationships though these visits was aided by the long-term experience that all four interviewers had living and working in the region. With each family, we spent half of the day in participant observation, visiting their farm (in $86 \%$ of cases), and joining in daily activities such as farming, housework, playing sports and eating meals. We contributed food to prepare lunch together to show a token of appreciation and avoid being a financial burden. The rest of the visit entailed a mean total of 6.5 hours of semi-structured and structured interviews dispersed throughout the day with both male and female household heads. The interview design was informed by half-day participatory workshops that we conducted in 2014 with separate groups of men and women in nine communities in the project areas (full details are available in Appendix B of the Supplemental Materials). We describe how these workshops specifically informed our various research methodologies below. 


\section{Understanding land use motivations and behaviors}

Rather than assuming that intervention participation is the most relevant factor shaping conservation behaviors (as impact evaluation studies tend to do), we first sought to understand the broad range of factors that shape people's land use behaviors. To identify potentially influential factors, we conducted the following exercises in our initial participatory workshops with communities in 2014: (1) mapping of common land uses, (2) wealth ranking, (3) discussion of food security, (4) personal and communal future visioning, (5) ranking of expressed values, and (6) listing of motivations for farm and forest management. The range of factors explored in workshops was informed by reviewing deforestation studies in diverse contexts (e.g. Angelsen \& Kaimowitz 2001; Agrawal \& Chhatre 2006; Farmar-Bowers \& Lane 2009; Calkins \& Thant 2011), and human behavioral theories from the fields of social psychology, behavioral economics and political ecology (e.g. Sen 1985; Bandura 1989; Stern et al. 1993; Frey \& Jegen 2001; Deci \& Ryan 2002; Ribot \& Peluso 2003; Fletcher 2010).

The findings of these workshops were used to develop locally appropriate methods to examine a wide range of factors potentially important for shaping farm and forest management, including forest access, economic and agricultural factors, motivations to conserve forests or expand farms and value orientations. Table 2 provides an overview of all of these variables, which were measured during 270 household visits to better understand deforestation behaviors (further methodological details are available in Appendix $\mathrm{C}$ of the Supplemental Materials). For example, the results of the wealth ranking exercise informed the selection of seven intercorrelated measures, which when combined through a principal component analysis (PCA), provided a locally meaningful and robust continuous measure of wealth across households. Distinct motivations for conservation were assessed by asking people a series of open questions about how they manage their land and forests, and then coding their explanations to identify the motivations that were mentioned and the strength they were expressed. Five major types of motivations were identified, including "intrinsic moral", "intrinsic use", "extrinsic material", "extrinsic law" and "not profitable" (see Table 2 for details). The consistency across all four interviewers was improved by coding based on a list of motivations identified in the workshops, jointly trialing methods and recording people's qualitative descriptions (see Appendix C).

In addition to specific motivations for conservation, several parts of the interview were designed to better understand people's values. The most notable distinctions among values expressed in the workshops closely followed Stern et al.'s (1993) biospheric, altruistic and egoistic categories; thus, locally appropriate methods were trialed to explore these values. For example, people were placed in hypothetical scenarios where they had to make trade-offs between personal, communal and ecological outcomes. These exercises produced measures that correlated with the extent to which respondents' future family and community visions expressed more biospheric, altruistic or egoistic values (based 
on qualitative coding). These data were combined through a PCA to provide a solid basis for comparing relative values across households. Two main value orientation axes emerged - 1) materialistic versus non-materialistic and 2) social versus ecological - which together explained $43 \%$ of the total variance (see value orientations in Table 2 and Appendix $\mathrm{C}$ for details).

Table 2. Explanatory variables for self-reported deforestation behaviors.

\begin{tabular}{|c|c|c|c|c|}
\hline Variable & Definition & Range & Mean & S.D. \\
\hline \multicolumn{5}{|l|}{ Forest access } \\
\hline Total forest area & Total area (hectares) of forest across landholdings & $0-142.5$ & 8.6 & 16.6 \\
\hline Altitude & Meters above sea level (masl) of main landholding & $181-1669$ & 869.4 & 396.3 \\
\hline \multicolumn{5}{|c|}{ Economic and agricultural factors } \\
\hline Market distance & Travel time (minutes) to reach nearest town with large market & $10-250$ & 64.1 & 50.9 \\
\hline Year began farming & Year obtained first land holding in the San Martin Region & $1965-2015$ & 1997 & 9.9 \\
\hline Total farmed area & $\begin{array}{l}\text { Total area (hectares) of farmed land, including cash crops, } \\
\text { pasture and staples }\end{array}$ & $0-41.5$ & 6.2 & 6.7 \\
\hline Area cash crops & Area (hectares) of cash crops (coffee, cacao, coconut, orange) & $0-22$ & 2.9 & 2.5 \\
\hline Area pasture & Area (hectares) of pasture & $0-35$ & 2.7 & 5.2 \\
\hline Area staples & Area (hectares) of staple crops (rice, maize, plantain) & $0-15$ & 0.5 & 1.3 \\
\hline Cash crop production & Annual production of all cash crops last year $(\mathrm{kg})$ & $0-22600$ & 1241 & 2186.5 \\
\hline Cash crop efficiency & Annual yield of cash crop last year (kg per hectare) & $0-3650$ & 382.1 & 523.5 \\
\hline Staple production & Annual production of all staple crops last year $(\mathrm{kg})$ & $0-39328$ & 831.6 & 3517.5 \\
\hline Wealth PC & $\begin{array}{l}\text { First principal component of wealth ranking variables } \\
\text { reflecting higher annual income, better household } \\
\text { infrastructure, goods and equipment, fewer days worked as a } \\
\text { daily wage laborer (explains } 37 \% \text { of total variance) }\end{array}$ & $-3.3-5.6$ & 0 & 1.6 \\
\hline On farm income & $\begin{array}{l}\text { Total income earned from farming activities last year (in } \\
\text { Peruvian Soles; } 1 \text { PEN }=0.31 \text { USD) }\end{array}$ & $\begin{array}{l}-4300- \\
72650\end{array}$ & 7168 & 9982.4 \\
\hline Farm labor income & Total income (PEN) earned from labor on farms last year & $0-18000$ & 1414 & 2590.5 \\
\hline Forest income & Total income (PEN) earned from forest products last year & $0-7200$ & 167 & 626.7 \\
\hline Off farm income & $\begin{array}{l}\text { Total income (PEN) earned from non-farming activities last } \\
\text { year (e.g. commercial, leasing property, transportation) }\end{array}$ & $0-28000$ & 2140 & 4195.6 \\
\hline Education level & Years of education completed by main farm manager & $0-16$ & 6 & 3.1 \\
\hline Need to expand & $\begin{array}{l}\text { Extent to which perceive need to expand farm to obtain } \\
\text { sufficient resources }(0-3 \text { scale; } 0=\text { do not need to expand at all, } \\
3=\text { situation is very bad if cannot expand })\end{array}$ & $0-3$ & 1.1 & 0.6 \\
\hline Food security PC & $\begin{array}{l}\text { First principal component of food security dimensions } \\
\text { reflecting less food shortage, higher perceived nutrient quality } \\
\text { and psychological security (explains } 56 \% \text { of total variance) }\end{array}$ & $-4.6-3.2$ & 0 & 1.3 \\
\hline Household size & Total number of people living in the household & $1-12$ & 4.5 & 1.9 \\
\hline \multicolumn{5}{|c|}{ Motivations to conserve } \\
\hline Intrinsic moral & $\begin{array}{l}\text { Extent values forest for ethically oriented intrinsic reasons } \\
\text { (e.g. wildlife, serenity, responsibility) }(1-5 \text { scale, where } 1=\text { no } \\
\text { expression, } 3=\text { medium expression, } 5=\text { very strong expression) }\end{array}$ & $1-5$ & 2.7 & 1.1 \\
\hline Intrinsic use & $\begin{array}{l}\text { Extent values forest for intrinsic resource use values (e.g. } \\
\text { water, forest products, fertile soil) (1-5 scale; same as above) }\end{array}$ & $1-5$ & 3.4 & 1.1 \\
\hline Extrinsic material & $\begin{array}{l}\text { Extent values forest for material/financial gain (e.g. direct } \\
\text { project benefits) ( } 1-5 \text { scale; same as above) }\end{array}$ & $1-4$ & 1.5 & 0.9 \\
\hline Extrinsic law & $\begin{array}{l}\text { Extent doesn't deforest because it is illegal and could receive } \\
\text { penalties ( } 1-5 \text { scale; same as above) }\end{array}$ & $1-5$ & 1.8 & 1.2 \\
\hline Not profitable & $\begin{array}{l}\text { Presence of economic reasons for not expanding (e.g. too old, } \\
\text { no time, no capital, poor land, risky) (binomial variable) }\end{array}$ & $0-1$ & 0.3 & 0.5 \\
\hline \multicolumn{5}{|l|}{ Value orientations } \\
\hline Materialistic PC & $\begin{array}{l}\text { First principal component of value orientation variables, } \\
\text { reflecting extent which prefer personal material outcomes over } \\
\text { social/ecological outcomes (explains } 23 \% \text { of total variance) }\end{array}$ & $-2.8-5.8$ & -0.1 & 1.1 \\
\hline Social-over-eco PC & $\begin{array}{l}\text { Second principal component of value orientation variables, } \\
\text { reflecting extent which prefer social outcomes over ecological } \\
\text { outcomes (explains } 21 \% \text { of total variance) }\end{array}$ & $-3.7-2.4$ & -0.1 & 1.1 \\
\hline
\end{tabular}




\section{Defining conservation outcomes}

Conservation outcomes are dynamic; for example, a household that deforested a lot in the past five years may plan to deforest relatively little during the next five years. It is also challenging to obtain accurate self-reported measures given farmer mistrust or recall problems. To manage these challenges we discussed farming histories in the context of a walking tour of farmers' land and spent an entire day with each family to build mutual trust and understanding. We also examined both recent past and future planned deforestation to provide a more robust exploration of explanatory variables: Model 1) whether or not farmers plan to deforest during the next 10 years ( $\mathrm{N}=270)$, Model 2) area farmers plan to deforest during the next 10 years (among farmers who plan to deforest; $\mathrm{N}=196$ ), Model 3) whether or not farmers self-reported deforesting during 2010-2014 (among those farming since 2010 who expressed that their present motivations for conservation had not recently changed; N=203), Model 4) area farmers reported deforesting during 2010-2014 (including farmers in model 3 who reported deforesting; $\mathrm{N}=93$ ) (see Table 3). The models investigated variables associated with the decision to deforest at all (binomial) versus how much to deforest (continuous). To account for the differential biodiversity impact of losing primary forests versus more degraded forest types, we conducted a sensitivity analysis for all models, where we weighted forest types in both explanatory and response variables. Models results were very robust to primary forest being valued more highly (Appendix C).

Table 3. Model outcome variables: self-reported deforestation behaviors.

\begin{tabular}{|c|c|c|c|c|c|}
\hline Variable & Definition & $\mathbf{N}$ & Range & Mean & S.D. \\
\hline \multicolumn{6}{|c|}{ Area plan to deforest $2016-2025$} \\
\hline Model 1 (binomial) & $\begin{array}{l}\text { Intention to deforest during next } 10 \text { years }(0=\text { no } \\
\text { intention, } 1=\text { has intention })\end{array}$ & 270 & $0-1$ & 0.7 & 0.5 \\
\hline Model 2 (continuous) & $\begin{array}{l}\text { Total area of forest types plan to convert (with } \\
\text { additional sensitivity analyses conducted, weighting } \\
\text { primary forest approximately double and triple } \\
\text { secondary/re-growth forest types - see Appendix C) }\end{array}$ & 196 & $0.1-28$ & 2.9 & 4.1 \\
\hline \multicolumn{6}{|c|}{ Area deforested $2010-2014$} \\
\hline Model 3 (binomial) & $\begin{array}{l}\text { Whether reported deforesting during the period } 2010 \\
-2014(0=\text { no, } 1=\text { yes })\end{array}$ & 203 & $0-1$ & 0.5 & 0.5 \\
\hline Model 4 (continuous) & $\begin{array}{l}\text { Sum of primary and secondary forest reported as } \\
\text { having deforested during the period } 2010-2014\end{array}$ & 93 & $0.3-12$ & 2.6 & 2.4 \\
\hline
\end{tabular}




\section{Exploring the political nature of participation}

Our research design focused equally on intervention participants and non-participants. Impact evaluation studies commonly do this to control for self-selection biases using matching methods or randomized control trials (e.g. Andam et al. 2008; Bulte et al. 2016). A limitation of such approaches is that participation in interventions is rarely random in practice, and thus it is critical to empirically investigate the implications of who participates, rejects participation, or cannot participate, and the reasons why (Cf. Li 2007; Svarstad \& Benjaminsen 2017). People do not receive a unidirectional "treatment" but rather play a very active role in how they will be treated, and who wins or loses as a result (Mosse 2005). We therefore asked each household about how they engaged with each current and recent past intervention in the area, their opinions of the work, and the reasons why they did or did not participate. One-way analysis of variance (ANOVA) tests were also performed to compare key features of participant and non-participant groups of interventions. This was not conducted to determine intervention impacts, given the self-selection biases, but rather to further explore the comparative characteristics of people who do versus do not participate in these interventions.

\section{Investigating intervention influence on motivations}

The common choice to use intervention participation as an explanatory variable can also obscure the causal chain between intervention actions and conservation outcomes. For example, interventions are highly heterogeneous and participation may mean very different things for different people, ranging from disillusionment over failed promises to genuine empowerment (Arnstein 1969). People's behavior is also impacted by many different factors over their lifetime, making it difficult to pinpoint exactly what produced a certain outcome and how long that outcome is likely to last.

In order to pick apart the mechanism by which distinct intervention strategies interacted with diverse local people, we first developed an understanding of what types of motivations people hold regarding management of forests on their land (through the mixed method technique previously described). The categorization of these motivations directly relates to various environmentalities. For example, neoliberal environmentality seeks to foster the desire to not deforest because of receiving (or promises to receive) material benefits (i.e. "extrinsic material"). Similarly, a certain forested area may be perceived as worthless to develop because it will not be financially productive (i.e. "not profitable"). Sovereign environmentality aims to prevent deforestation by creating a desire to follow the law and not receive punishment (i.e. "extrinsic law"). Disciplinary environmentality aims to instill a desire to not deforest because people value the intrinsic worth of forests, whether due to their direct use value (i.e. "intrinsic use") or deeper ethical considerations (i.e. "intrinsic moral"). 
For each household, the interview solicited a personal narrative of how they developed these motivations, including any relevant interactions with people or organizations. To assess how different combinations of environmentalities shaped motivations, we randomly selected 20 participants of each of the four main approaches outlined in Table 1 for in-depth qualitative analysis. We identified key storylines regarding the role of intervention forms in shaping personal motivations and then quantified their prevalence. We also analyzed personal accounts of how and why people expressing strong "intrinsic moral" motivations for conservation became motivated $(\mathrm{N}=67)$.

\section{Examining the link between motivations and behaviors}

The final part of the analysis sought to understand the behavioral implications of people holding combinations of these various motivations for conservation. We constructed regression models using the software R version 3.3.2 (R Development Core Team 2016) to explore how particular motivations and other explanatory factors (Table 2) are linked to recent past self-reported and future planned deforestation (Table 3). Generalized linear mixed models (GLMMs) were constructed to account for potential variation introduced by the crossed random effects of interviewer and community (Bolker et al. 2009). However, in all models the random effects were negligible, thus linear models (LMs) and generalized linear models (GLMs) were used. To strengthen the modeling approach given the large number of explanatory variables, we also constructed boosted regression trees (BRTs) for each outcome variable in order to identify the most independently influential explanatory variables for each outcome and potential interaction effects (Friedman 2001). The detailed procedure for the statistical analyses, including model verification, is provided in the Supplemental Materials (Appendix D). The statistical results could only indicate correlation and not causation; thus, we used the rich qualitative data we gathered from the day-long household visits to construct interpretations of potential causality. 


\section{Results: examining the implications of multiple environmentalities}

Across all four distinct combinations of environmentalities examined in this study, consistent stories emerged regarding their struggle to produce environmental subjects as intended. In this section, we describe four main reasons why these projects so often produced limited conservation outcomes in practice. Our interpretation is guided by the combined empirical insights of the four analytical components outlined in the methods section. Figure 4 outlines the implications of the existing motivations of those engaged by interventions, as well as the influence of intervention strategies on extrinsic and intrinsic motivations. Table 4 shows the explanatory variables that are most heavily associated with more or less self-reported deforestation behavior, including the role of the motivations that distinct environmentalities seek to develop. The statistical results are complemented by qualitative data that indicates causal relationships. These findings hold important implications for how common strategies rooted in these environmentalities shape projects in Peru and worldwide.

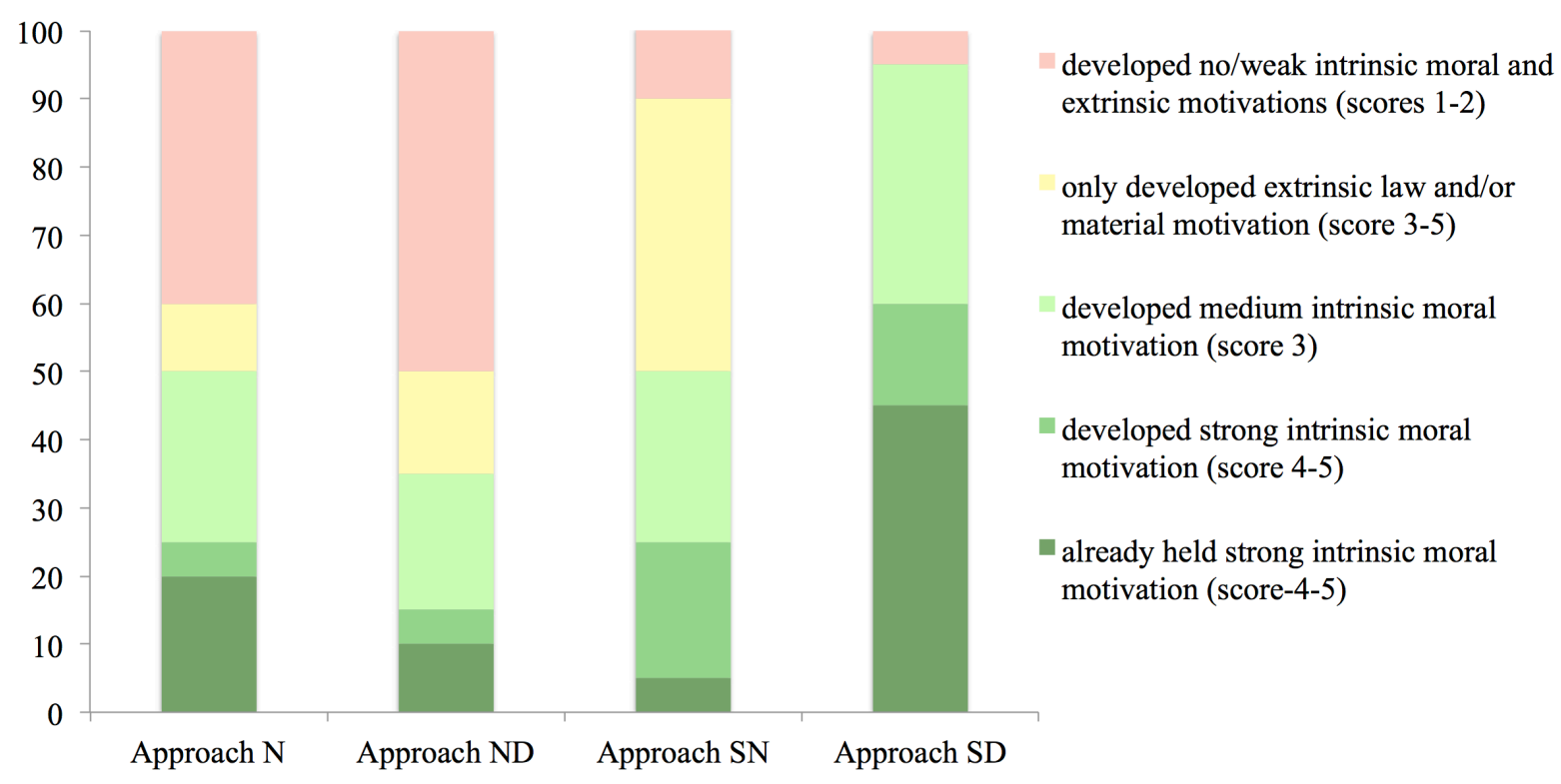

Figure 4. Breakdown of how participants' motivations were shaped for each intervention approach. Intrinsic use motivation was excluded because it was expressed by a majority of respondents ( $81 \%$ with score $3-5)$. 
Table 4. Regression analysis of deforestation behaviors. Colors denote: red = variable linked to higher deforestation, green $=$ variable linked to lower deforestation, yellow $=$ non-linear relationship. Variables and coefficient estimates not significant to $\mathrm{p}<0.10$ are not listed. Interactions terms are labeled A-Q; only interactions significant to $\mathrm{p}<0.01$ in the sensitivity analysis models were included to reduce potential type I errors. The overall explanatory power of the models $($ mean $=0.47$ ) is considered very good for an analysis of human behavior because it indicates that around half of the variance is being explained by the predictors. To further validate these relationships, partial dependency plots for the four strongest predictors of these models using Boosted Regression Trees are available in Appendix E.

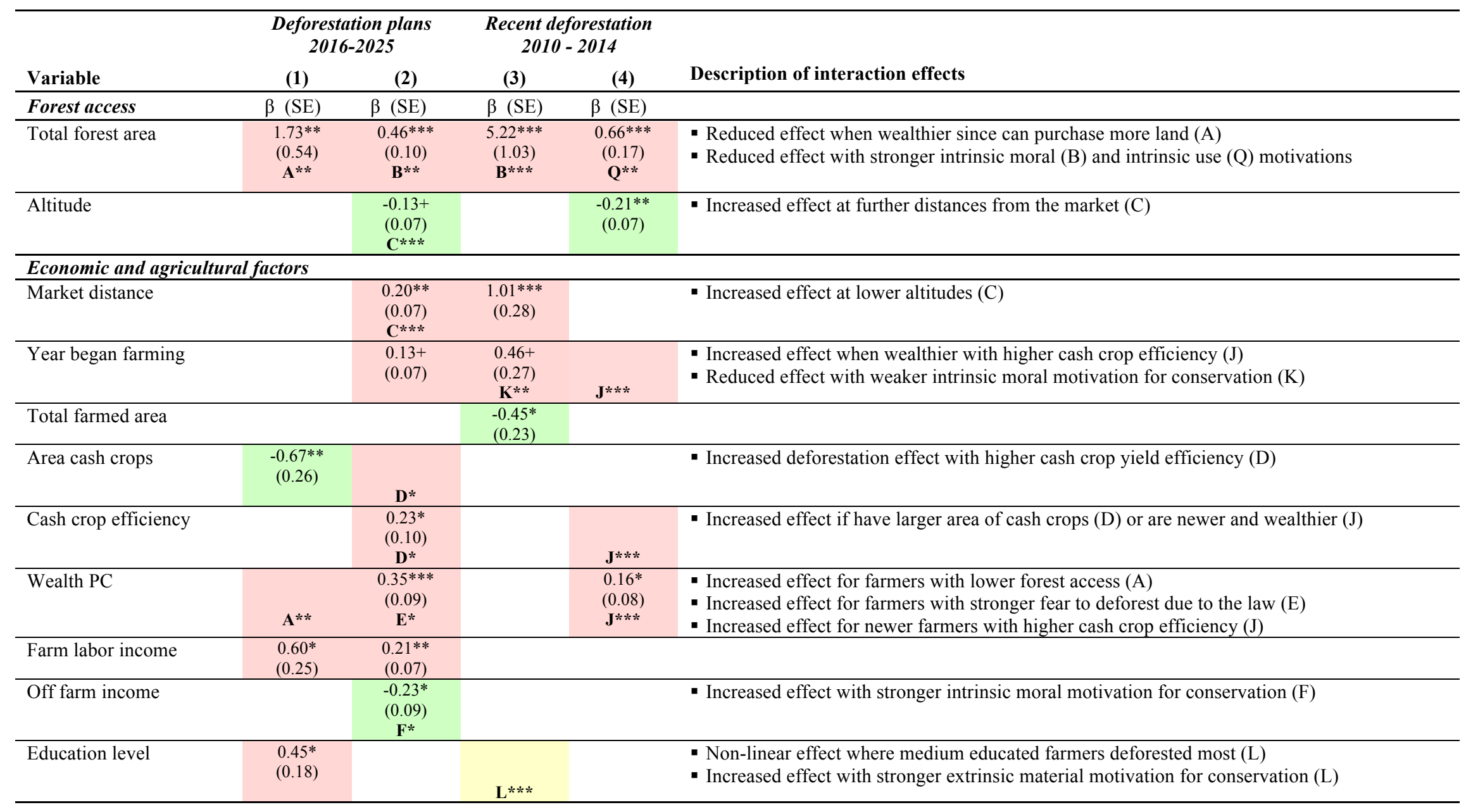




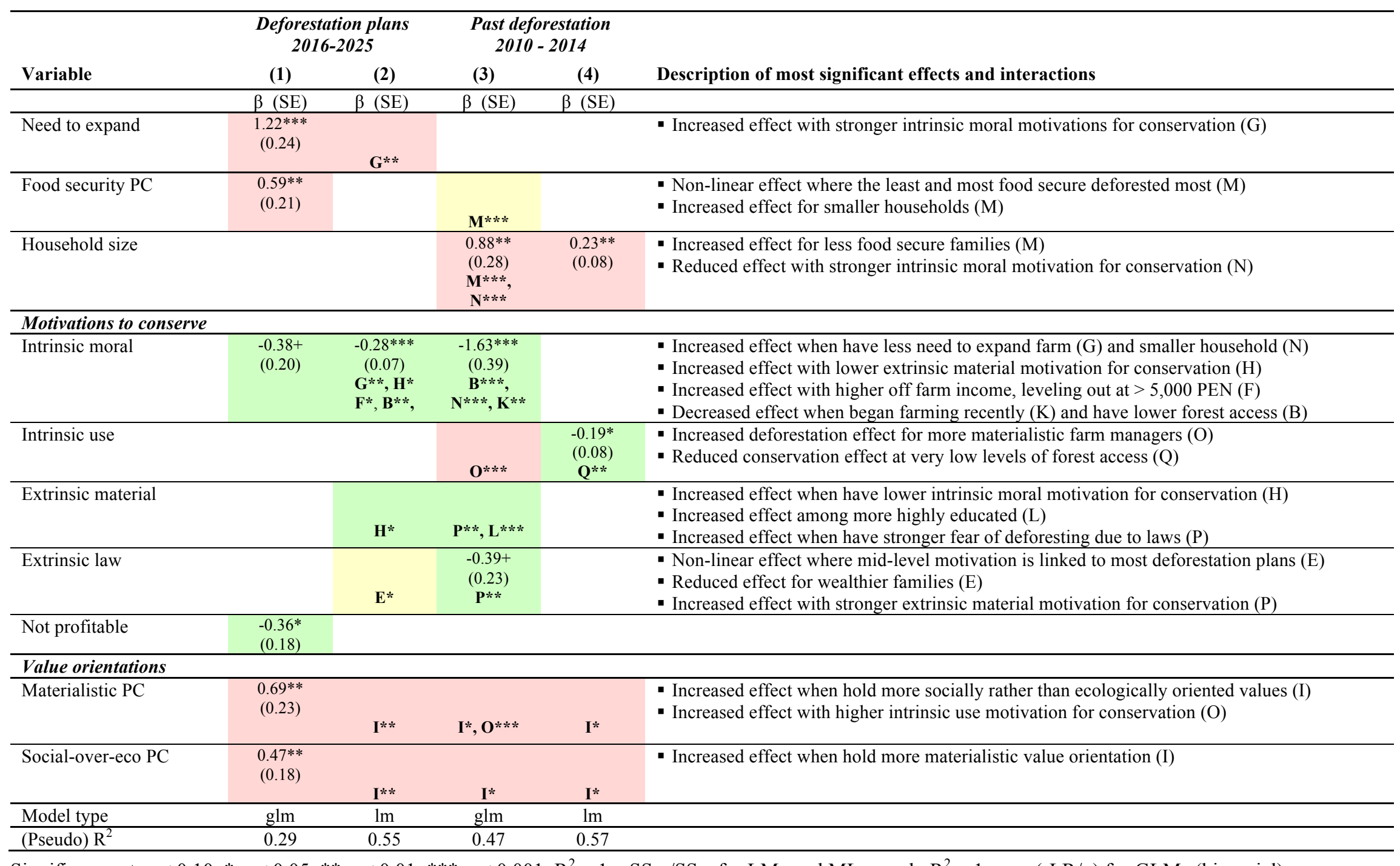

Significance: $+\mathrm{p}<0.10,{ }^{*} \mathrm{p}<0.05,{ }^{* *} \mathrm{p}<0.01,{ }^{* * *} \mathrm{p}<0.001 . \mathrm{R}^{2}=1-\mathrm{SS}_{\text {res }} / \mathrm{SS}_{\text {tot }}$ for $\mathrm{LMs}$ and ML pseudo $\mathrm{R}^{2}=1-\exp (-\mathrm{LR} / \mathrm{n}$ ) for GLMs (binomial). 


\section{Self-selection of like-minded individuals}

Our analysis demonstrated that projects typically engaged with actors who already best fit their notion of a successful environmental subject, dramatically reducing their potential impacts (Cf. Li 1999; Appadurai 2004). For example, projects that tried to alleviate poverty to incentivize conservation tended to attract farmers who were wealthier and more interested in farm development than conservation, regardless of whether environmental messages were included. Poorer families struggled to participate due to expensive membership fees, frequent meetings and more time and resourceintensive agricultural practices. Projects therefore reinforced existing social inequalities, as the poorest and least food secure families were often excluded from project benefits (Cf. Svarstad \& Benjaminsen 2017).

In contrast, when farmers had to demonstrate conservation outcomes to obtain support, such as by signing conservation agreements (e.g. PES schemes), participants often enrolled areas they were not planning to develop anyways - either due to economic reasons or preexisting conservation concerns. Those who avoided participating in these schemes typically felt that the support would not substitute for the cost of not expanding their farm, and were generally mistrustful of conservation organizations. Similarly, when incentives were offered to families living inside of protected areas, those who chose to participate revealed that they did so because they were already more in agreement with the law and had less need and/or desire to deforest. In contrast, the majority of farmers who chose not to receive support felt alienated by the imposed restrictions and did not want to participate in something they felt would "line the pockets" of the organizations responsible. Budgetary constraints meant that even if additional farmers chose to receive support over time, these requests could often not be fulfilled.

Conservation projects that primarily fostered environmental awareness most strongly self-selected people who already intrinsically cared about conservation (45\% of participants; Figure 4), as there were no extrinsic reasons to participate. However, the non-participants in these project areas held both significantly lower intrinsic moral motivation (Anova, $\mathrm{p}<0.01$ ) and higher rates of recent deforestation (Anova, $\mathrm{p}<0.01$ ), as compared to participants, having recently deforested on average more than nonparticipants of any other intervention form. This highlights potential limitations of insular community groups that do not effectively engage people who do not share their values.

This recurring dynamic of self-selection across all intervention forms was caused by organizations commonly expressing their fixed values and assumptions to promote participation in their fixed solution. As intervention impact evaluations tend to focus on how impacts are produced with beneficiaries instead of the implications of who participates, these limitations often go overlooked. 


\section{Weak link between extrinsic motivators and self-reported deforestation behavior}

Our analysis suggests a limited ability of incentives and laws to foster intended extrinsic motivations for conservation and translate those motivations into behavior change. Across projects where support was provided to sustainably intensify and certify crops (either inside or outside of protected areas), only $10 \%$ of participants felt motivated to conserve their forest due to material gain (Figure 4). In cases where support was not dependent on conditional conservation agreements, many farmers focused instead on translating efficiency gains into farm expansion instead of sparing forest habitat. Inside of protected areas, even if farmers received support, they typically did not feel that was a sufficient motivator to conserve, but were rather motivated by the restrictions, or due to an intrinsic interest in conservation. As one farmer expressed: "I almost went to jail for deforesting. I know the forests are important but the support is not sufficient. I want to expand my farm more, but I can't." This quote reflects how incentives often could not sufficiently compensate for the effects of restrictions.

Among the small portion of farmers who became motivated to conserve forest because they had received and/or were expecting project benefits (i.e. "extrinsic material" motivation), the regression analysis showed a limited effect on reducing reported deforestation behaviors. This effect was not direct, however, and was only significant for farmers with lower intrinsic moral motivation, higher extrinsic law motivation, or a higher education level, suggesting that incentives can in some cases make restrictions more palatable and incentivize small amounts of conservation (Table 4; interactions $\mathrm{H}, \mathrm{L}$ and P). These effects strengthened when primary forests were weighed more heavily in the analysis, although overall effects were still limited compared to other forms of motivation.

For the vast majority of farmers who did not become motivated to conserve for extrinsic material reasons, the regression analysis contradicts the central underlying assumption of these projects that if farmers can obtain higher crop yields and income then they will not need to deforest. Table 4 instead shows that greater wealth was actually consistently linked to increased deforestation. Qualitative data confirmed that this relationship is bidirectional - more deforestation leads to more wealth, which in turn facilitates more deforestation. People held expanding concepts of "need"; while poorer farming households stated their need to deforest a small area to feed their family, wealthier households stated their need to deforest to send their children to university. Only greater off farm income was linked to reduced deforestation. Conservation strategies that promote crop intensification therefore risk facilitating the tools for further expansion (Cf. Angelsen \& Kaimowitz 2001; Rudel et al. 2009).

Projects that use material incentives inside of protected areas seek to more directly couple increased crop efficiency to conservation gains. Such projects relied on the assumption that people will follow 
laws due to fear of punishment and can be convinced over time due to receiving tangible benefits. In practice, enforcement is often challenging; however, we purposefully focused on more heavily enforced areas to examine the effects. Indeed, many people were more motivated to conserve for extrinsic reasons in these settings $(40 \%$ - mostly due to "extrinsic law" motivation; Figure 4 approach $\mathrm{SN}$ ). Yet, the regression analyses revealed that this extrinsic motivation was not significantly linked to reduced deforestation (Table 4). The actual effect is likely even weaker, since some farmers living in protected areas could have felt compelled to artificially reduce their selfreported deforestation measures to hide illegal activities. This weak effect is due to two main reasons: (1) wealthier individuals managed to circumvent the law by purchasing land elsewhere or deforesting more between learning of the law and actual enforcement, and (2) people who held mid-range extrinsic law motivations (i.e. knew the law existed but felt it was poorly enforced) were most likely to state plans to deforest in the near future. As a result, the poorest families faced the heaviest burden of the restrictions despite planning relatively little expansion.

Our findings point to the highly limited role of extrinsic forms of motivation in producing long-term conservation behaviors due to farmers' abilities to resist and "sidetrack" these goals over time to suit their own goals (Cf. Büscher \& de Beer 2011; Cortes-Vazquez \& Ruiz-Ballesteros 2018). Any potential for material incentives and protected areas to generate lasting impacts therefore seems to depend on their ability to foster intrinsic motivations for conservation - an issue that will be examined in detail in the next section.

\section{Limited internalization of motivations to conserve}

Before examining the ability of interventions to foster intrinsic forms of motivation for conservation, we first discuss their behavioral implications. The regression analyses consistently identified intrinsic moral motivation for conservation as the strongest and most consistent type of motivation linked to reduced reported recent past and future planned deforestation (Table 4). This type of motivation also helped mitigate the effect of several economic factors on deforestation outcomes, such as higher forest access (interaction B), and was stronger amidst fewer economic trade-offs, such as having a smaller household and feeling less need to expand their farm (interactions $\mathrm{N}$ and $\mathrm{G}$ ). These findings suggest that the intrinsic desire to conserve for moral reasons has substantial direct and indirect effects on conservation behavior, but that competing development-oriented motivations also matter.

The more anthropocentric intrinsically held motivation to conserve forests - because of seeing them as important due to their provision of water and/or natural resources (i.e. "intrinsic use" motivation) alone guaranteed the conservation of only small areas (Table 4). As one farmer stated: "I am 
conserving the strip of trees around my stream because it's important for water, but in the rest of my forest I will plant more coffee." This finding points to the limits of only making the argument that people should conserve forest because it is in their self-interest to use its resources. This motivation, however, was highly complementary with intrinsic moral motivation $(\rho=0.61)$, and many people claimed how their awareness of the essential role forests play in community well-being caused them to care about forests for other reasons as well.

These empirical findings lead us to examine the following question - do material incentives and protected areas help internalize motivations to conserve? This is a popular claim that projects make through the storyline of a poor and unaware farmer who, after having received support, comes to realize the intrinsic importance of forests. This narrative is even commonly used by projects that only offer support and assume that benefits alone will foster more collective concerns (reminiscent of modernization theory - Inglehart \& Welzel 2005, and Maslow's hierarchy - Maslow 1954). Our analysis found that, in fact, wealthier farmers are no more likely to hold intrinsic moral motivation for conservation than poorer farmers. Projects that only offered material incentives strongly internalized intrinsic moral motivations with 5\% of farmers, and to a medium extent with $25 \%$ (Figure 4). These farmers most commonly cited long-term social interactions with project actors as having played an important role in shifting their values, thus the specific role of the material benefits remains unclear. The presence of project actors was intermittent for many other beneficiaries, though, and $45 \%$ felt that organizations were offering false promises and benefiting themselves more than farmers.

Projects that explicitly sought to increase environmental awareness alongside incentives, such as through PES schemes or by supporting community conservation associations, ironically resulted in less crowding in than the three other approaches (Figure 4; approach ND). For example, in both associations, the additional focus on gaining profitable opportunities for individual members shifted their focus away from conserving forests for collective reasons. In both cases, the community groups actively excluded more marginalized actors, as the desire to capture personal benefits not only attracted participants less intrinsically motivated for conservation (Figure 4), but also shaped the rules by which people could engage. As one participant explained: "There are people who criticize the association because they do not like that we receive support when they think it has arrived for the whole community. But it is for our association. It is good that people have to pay $500 \mathrm{~S} /$. to enter because we have worked hard to get where we are, spent money, and there are many benefits". This dynamic alienated many community members, who felt it was hypocritical that over half of the participants did not conserve forest on their private lands, despite financially benefiting from conservation of collective spaces (Figure 4). As a result of conflict both within and outside of these associations, $75 \%$ of its members felt dissatisfied and participation was declining. 
The use of incentives inside of protected areas led to higher levels of internalization than for areas outside of restrictions, with $20 \%$ of farmers having strongly embraced intrinsic moral motivations to conserve, and another $20 \%$ having partially done so (Figure 4). However, qualitative evidence suggested that for many other inhabitants, the laws had inhibited any potential intrinsic interest in conservation. As one non-participant described: “The laws don't let us work freely. Those who already have enough farm area can cooperate with the laws, while the many people who live farther away don't follow them." As a result, people rarely felt motivated for conservation due to both intrinsic moral reasons and restrictions $(\rho=-0.49)$, suggesting that the laws contributed to polarizing perspectives. Protected area management first focused on enforcing laws before trying to use more participatory methods, thus overlooking the potential of the former to inhibit the latter.

The limited ability of incentives and laws to internalize moral reasons to conserve, and additional counter-productive effects, raises the question - what approaches could potentially be more effective? Among projects that primarily focused on environmental awareness, 95\% of all participants held medium-strong intrinsic moral motivation for conservation on their private lands, as compared to just $35-50 \%$ of the other approaches. In addition, a much higher percentage of participants felt satisfied with these projects (90\%). However, as previously mentioned, this was partly due to attracting so many participants who were already motivated in this way (Figure 4). Nonetheless, by sharing social experiences in pursuit of collective forest conservation action, these community groups achieved internalization of moral motivations to conserve both collective and private forest with most of the remaining participants. The problem instead arose with how they struggled to constructively engage with many people in their community who were not interested in conservation.

These findings call for a much more sophisticated conceptualization of how people come to embrace new moral values. Based on this empirical study and relevant theory on this topic, people's sense of self-autonomy and the experiences they share with people they trust around topics of concern seem to play a crucial role (see self-determination theory; Deci \& Ryan 1980, 2012). There is a clear need for better ways of negotiating competing values and motivations within communities and with external actors. By presenting local actors with fixed problem and solution frames (see Figure 1), neither intervention actors nor local people are empowered to deliberate and reframe their perspectives.

\section{Ignored broader economic drivers of deforestation}

Our analysis goes a step beyond examining the intended outcomes of interventions by also examining the broader array of factors that facilitate deforestation. For example, the regression analysis and qualitative data revealed that the strongest factors driving deforestation were related to people's 
possibilities and desire to materially develop, such as their forest access, distance to market, wealth, household size, cash crop efficiency, perceived need to expand their crops and materialistic values (Table 4). Even farmers with strong intrinsic moral motivation for conservation were heavily influenced by economic opportunities due to selective moral disengagement (see Bandura 2002). For example, one wealthier farmer commented: "I need to plant 10 more hectares for my cattle, but I plan to conserve the other 10 hectares of my primary forest for the little animals and because it is important for water".

Many conservation interventions therefore either did not attempt to shape these broader economic drivers, or may have even exacerbated them. For example, neoliberal environmentalities have quickly spread across the region over the past decade, yet these strategies seek to increase (not reduce) private income and reinforce (rather than challenge) materialistic motivations to develop. Other interventions, such as intrinsically motivated community conservation groups struggled to establish rules that were seen as legitimate amidst these external pressures and high levels of in-migration. An important tension therefore exists between the need for conservation interventions to engage, on the one hand, in long-term and in-depth ways in local settings to open possibilities to navigate and reframe competing motivations, and on the other land, to extend beyond their local focus. Any attempt to shape the broader drivers that accumulate land and wealth in the hands of people who are materialistically driven to develop them requires actions at regional, national and even international scales. The next section discusses this dual challenge and the possibility for environmentality theory to inform it.

\section{Discussion: advancing the theory and practice of multiple environmentalities}

The discursive power of the popular approaches to joint conservation and development examined in this study lies in the partial truth of their assumptions. It is easy to agree that human behavior can simultaneously be shaped by all three environmentalities. Indeed, the presence of these multiple motivations for conservation - authority, benefits, values and norms - in a local setting, when working in concert, could potentially produce long-term conservation results. The problem seems to arise with how interventions often embrace one particular story above all others about how people can become motivated for conservation and then employ top-down technical efforts to implement their proposed solution. This occurs when actors assume they know the best law (e.g. 8 years in jail), incentive (e.g. increased coffee yields) and/or message (e.g. the importance of endangered species) to appeal to people and thus further their effort.

Such approaches are divorced from the realities of local contexts and can lead project managers and donors to believe that joint protected area formation, livelihood improvement and community-based 
initiatives are naturally complementary to produce "ideal" conservation-productive landscapes. Yet, this analysis demonstrated how strategies to produce single or multiple motivations for conservation often generate tensions that can hinder long-term conservation outcomes. For example, imposing protected area laws alienated local people, generated social conflict, and inhibited the development of autonomous motivation for conservation, while wealthier actors managed to avoid many of their effects. Similarly, projects that sought to strengthen community conservation associations by providing individual incentives paradoxically weakened them by encouraging exclusive practices, generating social conflict, and inhibiting the development of more inclusive processes driven by collective concerns. The findings of this study also pose challenges to the equitability of these approaches to conservation, as richer farmers were planning to deforest more and thus would require the most benefits through a "win-win" approach (Cf. Muradian 2013).

These popular approaches to conservation experienced limited success in northern Peru due to overlooking the importance of the process by which benefits are framed, distributed and meaning is generated. They also overlooked the process by which laws and norms are socially constructed and given meaning in their process of being defined, developed, and interpreted. Finally, they overlooked the process by which new values may become integrated with existing values in unplanned ways within individual subjects and communal spaces, and in particular, the role of autonomy and social relatedness in crowding in new values and norms (Deci \& Ryan 2012). By making fixed assumptions about people's motivations, interventions tended to attract like-minded perspectives and reinforce these motivations. This inhibited their ability to engage more diverse perspectives in deliberative processes that might challenge people's motivations and open up new governance pathways.

In order to shift conservation outcomes in local settings, the processes by which multiple types of motivations are navigated and reframed by both local and external actors is therefore critical for establishing new forms of governance (see "constitutionality" - Haller et al. 2016; "co-productive governance" - Wyborn 2015); "social learning" - Ison et al. 2015; "agonistic pluralism" - Matulis \& Moyer 2017). This entails focusing not only on how motivations for conservation are developed (i.e. environmentalities), but also how motivations for development are developed (i.e. developmentalities), and the role of both local and non-local influences. In the literature, the term "developmentality" has been used to refer to a rationality of government which seeks to shape its subjects in ways which constrain their self understanding and cause them to adopt policies and values - primarily neoliberal ones (Lie 2004; Ilcan \& Phillips 2010). However, there has been less attention to how various policies and practices seek to engender distinct forms of developmental subjectivity, such as self-enhancement versus self-transcendence and openness versus resistance to change, and how these interact with environmentalities (Schwartz 1992, 2012). 
The potential for the multiple environmentalities framework to inform this effort depends on moving beyond analyses that emphasize the top-down creation of "environmental subjects". Instead, it necessitates recognizing how local actors co-produce the outcomes of interventions in unplanned ways (Cf. Cepek 2011; Cortes-Vazquez \& Ruiz-Ballesteros 2018). However, it requires going a step further than this by asking what alternative processes can respect the self-determination and agency of people while facilitating their ability to navigate among competing environmentalities and developmentalities to prioritize long-term collective goods. At a practical level, this requires donors and project managers to not initiate dialogue through the lens of the fixed problem and solution frames that the various environmentalities entail. Rather, it requires them to acknowledge diverse views as a starting point to then search for and build common ground. Finally, the findings of this study caution against overly romanticizing environmentality theory through a 'local' lens. Rather, it is critical to also extend this analytical lens upward to explore competing motivations with people who are intricately involved in distributing resources and ideologies in ways that reinforce the status quo in conservation and development. Such efforts require funding structures and timelines that support long-term forms of engagement that connect across scales.

\section{Conclusion}

The findings of this study raise serious questions regarding the impacts of conservation strategies that are commonly used across this landscape in northern Peru, as well as globally. Our analysis identified four major explanations for why conservation projects in northern Peru often fail, regardless of the combinations of environmentalities they employ. These findings raise several key issues that inform ongoing debates about the role of incentives and protected areas in conservation initiatives.

First, it is essential to reconsider the process by which interventions seek participation. Projects framed primarily as productive opportunities more successfully engaged people who were not necessarily interested in conservation, yet rarely internalized conservation values over time. Alternatively, projects framed in conservation language attracted like-minded individuals, leaving opposing perspectives by the way side. The self-selection bias of such projects, which typically have limited funds and opportunistically work with those who are more interested and already meet the criteria for success, often result in the weak additionality of these projects, and can further polarize perspectives.

Second, the theory and practice behind how material incentives and governance regimes may help to crowd in intrinsic long-term motivation for conservation remains poorly understood. In San Martin, 
the commonly put forward narrative that material incentives and protected areas provide an easy pathway to long-term forest "allies" was substantially overstated. Urgent attention is needed to explore more collaborative approaches that can support people to express their sense of autonomy to forge multiple pathways by which people may become motivated for conservation.

Third, the broader economic drivers that substantially limit possible outcomes in local settings necessitate linking local forms of conservation governance to intervention efforts at higher scales. Across these scales, this requires improved understanding of processes that can facilitate interactions among competing conservation and development motivations to reframe perspectives and establish new governance arrangements.

The multiple environmentalities framework can help inform these practical efforts through several avenues of future research. First, the literature suggests that many of the dynamics we find in northern Peru are likely more broadly applicable, thus similar in-depth examinations are needed in other contexts. Second, future environmentalities research should extend beyond simply critiquing how combinations of strategies play out in local settings. Rather, the framework holds great potential to inform how environmental policies and processes can actively facilitate diverse actors to explore and reshape their motivations, behaviors and governance arrangements to further conservation and wellbeing aims.

Third, there is a need to explore these processes - not only in local settings - but also in regional, national and global settings, and to connect these efforts. Finally, we have provided an explanation of why projects rooted in these environmentalities tend to fail on the ground in Peru. However, this says nothing about why these dominant ways of seeing and addressing conservation challenges continue to be reinforced throughout global networks. Thus, a ripe area for future research is to understand the processes that reinforce these globally circulating forms of expertise and to constructively seek to challenge them to create more diverse approaches to seeing and addressing environmental problems.

\section{Declaration of conflicting interests}

The author(s) declared no potential conflicts of interest with respect to the research, authorship, and/or publication of this article. 


\section{References}

Adams W, Hutton J. 2007. People, Parks and Poverty: Political Ecology and Biodiversity Conservation. Conservation and Society 5:147.

Adams WM, Aveling R, Brockington D, Dickson B, Elliott J, Hutton J, Roe D, Vira B, Wolmer W. 2004. Biodiversity Conservation and the Eradication of Poverty. Science 306:1146-1149.

Agrawal A. 2005. Environmentality: technologies of government and the making of subjects. Duke University Press.

Agrawal A, Chhatre A. 2006. Explaining success on the commons: Community forest governance in the Indian Himalaya. World Development 34:149-166.

Agrawal A, Redford K. 2006. Poverty, development, and biodiversity conservation: shooting in the dark? Working paper no. 26. Wildlife Conservation Society, New York, USA.

Andam KS, Ferraro PJ, Pfaff A, Sanchez-Azofeifa GA, Robalino JA. 2008. Measuring the effectiveness of protected area networks in reducing deforestation. Proceedings of the National Academy of Sciences 105:16089-16094.

Angelsen A, Kaimowitz D, editors. 2001. Agricultural technologies and tropical deforestation. Center for International Forestry Research (CIFOR)/CABI Publishing, Indonesia/UK.

Appadurai A. 2004. The Capacity to Aspire: Culture and the Terms of Recognition. Page in V. Rao and M. Walton, editors. Culture and Public Action. Stanford University Press, Stanford.

Arnstein SR. 1969. A Ladder Of Citizen Participation. Journal of the American Institute of Planners 35:216-224.

Baker J, Bitariho R, Gordon-Maclean A, Kasoma P, Roe D, Sheil D, Twinamatsiko M, Tumushabe G, Heist M van, Weiland M. 2013. Linking protected area conservation with poverty alleviation in Uganda: integrated conservation and development at Bwindi Impenetrable National Park. Pages 47-103 in J. B. Smith, editor. National parks: sustainable development, conservation strategies and environmental impacts. Nova Science Publishers, Inc. Available from https://epubs.scu.edu.au/esm_pubs/2189.

Bandura A. 1989. Human Agency in Social Cognitive Theory. American Psychologist 44:1175-1184.

Bandura A. 2002. Selective Moral Disengagement in the Exercise of Moral Agency. Journal of Moral Education 31:101-119.

Barlow J et al. 2007. Quantifying the biodiversity value of tropical primary, secondary, and plantation forests. Proceedings of the National Academy of Sciences 104:18555-18560.

Barton DN, Benavides K, Chacon-Cascante A, Coq J-FL, Quiros MM, Porras I, Primmer E, Ring I. 2017. Payments for Ecosystem Services as a Policy Mix: Demonstrating the institutional analysis and development framework on conservation policy instruments. Environmental Policy and Governance 27:404-421.

Belcher B, Ruíz-Pérez M, Achdiawan R. 2005. Global patterns and trends in the use and management of commercial NTFPs: Implications for livelihoods and conservation. World Development 33:1435-1452.

Blackman A, Naranjo MA. 2012. Does eco-certification have environmental benefits? Organic coffee in Costa Rica. Ecological Economics 83:58-66.

Blackman A, Rivera J. 2010. The evidence base for environmental and social impacts of "sustainable" certification. Discussion paper, Resources for the Future, Washington, DC.

Blom B, Sunderland T, Murdiyarso D. 2010. Getting REDD to work locally: lessons learned from integrated conservation and development projects. Environmental Science \& Policy 13:164172.

Bluwstein J. 2017. Creating ecotourism territories: Environmentalities in Tanzania's communitybased conservation. Geoforum 83:101-113.

Bolker BM, Brooks ME, Clark CJ, Geange SW, Poulsen JR, Stevens MHS, White J-SS. 2009. 作 Trends in Ecology \& Evolution 24:127-135.

Bonham CA, Sacayon E, Tzi E. 2008. Protecting imperiled "paper parks": potential lessons from the Sierra Chinajá, Guatemala. Biodiversity and Conservation 17:1581-1593. 
Borgerhoff Mulder M, Coppolillo P. 2005. Conservation: Linking Ecology, Economics, and Culture. Princeton University Press.

Börner J, Baylis K, Corbera E, Ezzine-de-Blas D, Ferraro PJ, Honey-Rosés J, Lapeyre R, Persson UM, Wunder S. 2016. Emerging Evidence on the Effectiveness of Tropical Forest Conservation. PLOS ONE 11:e0159152.

Bowler DE, Buyung-Ali LM, Healey JR, Jones JP, Knight TM, Pullin AS. 2012. Does community forest management provide global environmental benefits and improve local welfare? Frontiers in Ecology and the Environment 10:29-36.

Brashares JS, Golden CD, Weinbaum KZ, Barrett CB, Okello GV. 2011. Economic and geographic drivers of wildlife consumption in rural Africa. Proceedings of the National Academy of Sciences 108:13931-13936.

Brockington D. 2003. Injustice and conservation - is "local support" necessary for sustainable protected areas? Policy Matters:22-30.

Brockington D, Igoe J. 2006. Eviction for Conservation: A Global Overview. Conservation and Society 4:424.

Brooks JS. 2016. Design features and project age contribute to joint success in social, ecological, and economic outcomes of community-based conservation projects. Conservation Letters 10:2332.

Bulte E, Conteh B, Kontoleon A, List J, Mokuwa E, Richards P, Turley T, Voors M. 2016. The impact of earned and windfall cash transfers on livelihoods and conservation in Sierra Leone, 3ie Impact Evaluation Report 46. International Initiative for Impact Evaluation (3ie), New Delhi.

Büscher B et al. 2017. Half-Earth or Whole Earth? Radical ideas for conservation, and their implications. Oryx 51:407-410.

Büscher B, de Beer E. 2011. The contemporary paradox of long-term planning for social-ecological change and its effects on the discourse-practice divide: evidence from Southern Africa. Journal of Environmental Planning and Management 54:301-318.

Büscher B, Fletcher R. 2015. Accumulation by Conservation. New Political Economy 20:273-298.

Büscher B, Sullivan S, Neves K, Igoe J, Brockington D. 2012. Towards a synthesized critique of neoliberal biodiversity conservation. Capitalism Nature Socialism 23:4-30.

Calkins P, Thant PP. 2011. Sustainable agro-forestry in Myanmar: from intentions to behavior. Environment, Development and Sustainability 13:439-461.

Cepek M. 2011. Foucault in the forest: Questioning environmentality in Amazonia. American Ethnologist 38:501-515.

Chhatre A, Agrawal A. 2009. Trade-offs and synergies between carbon storage and livelihood benefits from forest commons. Proceedings of the National Academy of Sciences 106:1766717670.

Clough Y, Faust H, Tscharntke T. 2009. Cacao boom and bust: sustainability of agroforests and opportunities for biodiversity conservation. Conservation Letters 2:197-205.

Corbera E, Brown K, Adger WN. 2007. The equity and legitimacy of markets for ecosystem services. Development and Change 38:587-613.

Cortes-Vazquez J, Ruiz-Ballesteros E. 2018. Practising Nature: A Phenomenological Rethinking of Environmentality in Natural Protected Areas in Ecuador and Spain. Conservation and Society:1-11.

Crook C, Clapp RA. 2002. The paradox of market-oriented conservation: lessons from the tropical forests. Pages 163-179 in E. T. Jones, R. J. McLain, and J. Weigand, editors. Nontimber Forest Products in the United States. University Press of Kansas, Lawrence.

Curran LM, Trigg SN, McDonald AK, Astiani D, Hardiono YM, Siregar P, Caniago I, Kasischke E. 2004. Lowland Forest Loss in Protected Areas of Indonesian Borneo. Science 303:10001003.

Deci EL, Ryan M. 2012. Motivation, personality, and development within embedded social contexts: an overview of Self-Determination Theory. Page The Oxford Handbook of Human Motivation. Oxford University Press, USA.

Deci EL, Ryan RM. 1980. The Empirical Exploration of Intrinsic Motivational Processes. Pages 3980 in Leonard Berkowitz, editor. Advances in Experimental Social Psychology. Academic 
Press. Available from http://www.sciencedirect.com/science/article/pii/S0065260108601306 (accessed August 29, 2014).

Deci EL, Ryan RM. 2002. Handbook of Self-determination Research. University of Rochester Press.

Douglas M. 1970. Natural Symbols: Explorations in Cosmology. Barrie \& Rockliff, Cresset Press, London; New York.

Douglas M. 1978. Cultural Bias. Royal Anthropological Institute of Great Britan and Ireland. Available from http://trove.nla.gov.au/version/9867936.

Dressler W, Büscher B, Schoon M, Brockington D, Hayes T, Kull CA, McCarthy J, Shrestha K. 2010. From hope to crisis and back again? A critical history of the global CBNRM narrative. Environmental Conservation 37:5-15.

Ellis EA, Porter-Bolland L. 2008. Is community-based forest management more effective than protected areas?: A comparison of land use/land cover change in two neighboring study areas of the Central Yucatan Peninsula, Mexico. Forest Ecology and Management 256:1971-1983.

Ewers RM, Rodrigues ASL. 2008. Estimates of reserve effectiveness are confounded by leakage. Trends in Ecology \& Evolution 23:113-116.

Fairhead J, Leach M, Scoones I. 2012. Green Grabbing: a new appropriation of nature? The Journal of Peasant Studies 39:237-261.

Farley J, Costanza R. 2010. Payments for ecosystem services: From local to global. Ecological Economics 69:2060-2068.

Farmar-Bowers Q, Lane R. 2009. Understanding farmers' strategic decision-making processes and the implications for biodiversity conservation policy. Journal of Environmental Management 90:1135-1144.

Ferraro PJ, Hanauer MM, Miteva DA, Canavire-Bacarreza GJ, Pattanayak SK, Sims KRE. 2013. More strictly protected areas are not necessarily more protective: evidence from Bolivia, Costa Rica, Indonesia, and Thailand. Environmental Research Letters 8:025011.

Fisher J. 2012. No pay, no care? A case study exploring motivations for participation in payments for ecosystem services in Uganda. Oryx 46:45-54.

Fletcher R. 2010. Neoliberal environmentality: Towards a poststructuralist political ecology of the conservation debate. Conservation and Society 8:171.

Fletcher R. 2017. Environmentality unbound: Multiple governmentalities in environmental politics. Geoforum 85:311-315.

Foucault M. 1980. Power/Knowledge: Selected Writings and Other Interviews 1972-1977. Page (Gordon C, editor). Pantheon, New York.

Foucault M. 1994. Power. The New Press, New York.

Foucault M. 2008. The birth of biopolitics. Palgrave Macmillan, New York.

Frey BS, Jegen R. 2001. Motivation Crowding Theory. Journal of Economic Surveys 15:589-611.

Friedman JH. 2001. Greedy function approximation: A gradient boosting machine. The Annals of Statistics 29:1189-1232.

Gan J, McCarl BA. 2007. Measuring transnational leakage of forest conservation. Ecological Economics 64:423-432.

Haller T, Acciaioli G, Rist S. 2016. Constitutionality: Conditions for Crafting Local Ownership of Institution-Building Processes. Society \& Natural Resources 29:68-87.

Haller T, Belsky JM, Rist S. 2018. The Constitutionality Approach: Conditions, Opportunities, and Challenges for Bottom-Up Institution Building. Human Ecology 46:1-2.

Hutton J, Adams WM, Murombedzi JC. 2005. Back to the Barriers? Changing Narratives in Biodiversity Conservation. Forum for Development Studies 2:341-370.

Ilcan S, Phillips L. 2010. Developmentalities and Calculative Practices: The Millennium Development Goals. Antipode 42:844-874.

Inglehart R, Welzel C. 2005. Modernization, Cultural Change, and Democracy: the human development sequence. Cambridge University Press, Cambridge, UK.

Ison RL, Collins KB, Wallis PJ. 2015. Institutionalising social learning: Towards systemic and adaptive governance. Environmental Science \& Policy 53:105-117.

Kallis G, Gómez-Baggethun E, Zografos C. 2013. To value or not to value? That is not the question. Ecological Economics 94:97-105. 
Karsenty A, Aubert S, Brimont L, Dutilly C, Desbureaux S, Blas DE de, Velly GL. 2017. The Economic and Legal Sides of Additionality in Payments for Environmental Services. Environmental Policy and Governance 27:422-435.

Kilbane Gockel C, Gray LC. 2009. Integrating Conservation and Development in the Peruvian Amazon. Ecology and Society 14:11.

Kusters K, Achdiawan R, Belcher B, Ruiz Pérez M. 2006. Balancing development and conservation? An assessment of livelihood and environmental outcomes of nontimber forest product trade in Asia, Africa, and Latin America. Ecology and Society 11:20.

la Mesa REDD+ San Martín. 2013. Estrategia REDD+ en la región San Martín: Parte I: Diagnóstico para la Implementación del Mecanismo REDD+ JNR: Documento De Trabajo.

Lele S, Wilshusen P, Brockington D, Seidler R, Bawa K. 2010. Beyond exclusion: alternative approaches to biodiversity conservation in the developing tropics. Current Opinion in Environmental Sustainability 2:94-100.

Li TM. 1999. Compromising Power: Development, Culture, and Rule in Indonesia. Cultural Anthropology 14:295-322.

Li TM. 2007. The Will to Improve: Governmentality, Development, and the Practice of Politics. Duke University Press, Durham, NC.

Lie JHS. 2004. Discursive development order and local informal practices : a development project in Northern Ethiopia. Available from https://www.duo.uio.no/handle/10852/16548 (accessed April 16, 2018).

Lybbert TJ, Aboudrare A, Chaloud D, Magnan N, Nash M. 2011. Booming markets for Moroccan argan oil appear to benefit some rural households while threatening the endemic argan forest. Proceedings of the National Academy of Sciences 108:13963-13968.

Madhusudan MD. 2005. The global village: Linkages between international coffee markets and grazing by livestock in a south Indian wildlife reserve. Conservation Biology 19:411-420.

Martinez-Vasquez J. 2013. Fiscal Decentralization in Peru: A Perspective on Recent Developments and Future Challenges. Working Paper 13-24. International Center for Public Policy, Georgia State University.

Maslow AH. 1954. Motivation and personality. Harper.

Matulis BS, Moyer JR. 2017. Beyond Inclusive Conservation: The Value of Pluralism, the Need for Agonism, and the Case for Social Instrumentalism. Conservation Letters 10:279-287.

McAfee K. 1999. Selling nature to save it? Biodiversity and green development. Environment and Planning D: Society and Space 17:133-154.

McShane TO et al. 2011. Hard choices: Making trade-offs between biodiversity conservation and human well-being. Biological Conservation 144:966-972.

MINAM. 2009. Mapa de deforestación de la Amazonía Peruana 2000. Ministerio del Ambiente (MINAM), Lima, Peru.

Miteva DA, Pattanayak SK, Ferraro PJ. 2012. Evaluation of biodiversity policy instruments: what works and what doesn't? Oxford Review of Economic Policy 28:69-92.

Mosse D. 2005. Cultivating Development: An Ethnography of Aid Policy and Practice. Pluto Press, London.

Muradian R et al. 2013. Payments for ecosystem services and the fatal attraction of win-win solutions. Conservation Letters 6:274-279.

Muradian R. 2013. Payments for Ecosystem Services as Incentives for Collective Action. Society \& Natural Resources 26:1155-1169.

Nakamura K. 2017. Mapping the funding landscape for biodiversity conservation in Peru. Masters. University of Illinois at Urbana-Champaign, Illinois, USA.

Oates JF. 1995. The dangers of conservation by rural development - a case-study from the forests of Nigeria. Oryx 29:115-122.

Ostrom E, Nagendra H. 2006. Insights on linking forests, trees, and people from the air, on the ground, and in the laboratory. Proceedings of the National Academy of Sciences 103:1922419231.

Pagiola S. 2008. Payments for environmental services in Costa Rica. Ecological Economics 65:712724. 
Persha L, Agrawal A, Chhatre A. 2011. Social and ecological synergy: Local rulemaking, forest livelihoods, and biodiversity conservation. Science 331:1606-1608.

Pokorny B, Johnson J, Medina G, Hoch L. 2012. Market-based conservation of the Amazonian forests: Revisiting win-win expectations. Geoforum 43:387-401.

R Development Core Team. 2016. R: A Language and Environment for Statistical Computing. R Foundation for Statistical Computing, Vienna, Austria. Available from https://www.rproject.org/.

Redford KH. 1991. The ecologically noble savage. Cultural Survival Quarterly 15:412-422.

Ribot JC, Peluso NL. 2003. A Theory of Access*. Rural Sociology 68:153-181.

Rode J, Gómez-Baggethun E, Krause T. 2015. Motivation crowding by economic incentives in conservation policy: A review of the empirical evidence. Ecological Economics 117:270-282.

Roe D. 2008. The origins and evolution of the conservation-poverty debate: a review of key literature, events and policy processes. Oryx 42:491-503.

Roe D, Fancourt M, Sandbrook C. 2015. Biodiversity conservation and poverty reduction: what's the connection? A systematic mapping of the evidence. IIED Research Report, London.

Roe D, Hutton J, Elliott J, Chitepo K, Saruchera M. 2003. In pursuit of pro-poor conservation changing narratives... or more? Policy Matters 12.

Rosa H, Kandel S, Dimas L. 2003. Compensation for environmental services and rural communities. Lessons from the Americas and key issues for strengthening community strategies. Programa Salvadoreno de Investigacion Sobre Desarrollo y Medio (PRISMA), San Salvador, El Salvador.

Rudel TK et al. 2009. Agricultural intensification and changes in cultivated areas, 1970-2005. Proceedings of the National Academy of Sciences 106:20675-20680.

Samii C, Paler L, Chavis L, Kulkarni P, Lisiecki M, Samii C, Paler L, Chavis L, Kulkarni P, Lisiecki M. 2014. Effects of Decentralized Forest Management (DFM) on Deforestation and Poverty in Low and Middle Income Countries: A Systematic Review. Campbell Systematic Reviews 10.

Schwartz S. 2012. An Overview of the Schwartz Theory of Basic Values. Online Readings in Psychology and Culture 2. Available from https://scholarworks.gvsu.edu/orpc/vol2/iss1/11.

Schwartz SH. 1992. Universals in the Content and Structure of Values: Theoretical Advances and Empirical Tests in 20 Countries. Pages 1-65 in M. P. Zanna, editor. Advances in Experimental Social Psychology. Academic Press.

Sen A. 1985. Well-Being, Agency and Freedom: The Dewey Lectures 1984. The Journal of Philosophy 82:169.

Sims KRE. 2010. Conservation and development: Evidence from Thai protected areas. Journal of Environmental Economics and Management 60:94-114.

Sommerville M, Jones JPG, Rahajaharison M, Milner-Gulland EJ. 2010a. The role of fairness and benefit distribution in community-based Payment for Environmental Services interventions: A case study from Menabe, Madagascar. Ecological Economics 69:1262-1271.

Sommerville M, Milner-Gulland E j., Rahajaharison M, Jones JP g. 2010b. Impact of a CommunityBased Payment for Environmental Services Intervention on Forest Use in Menabe, Madagascar. Conservation Biology 24:1488-1498.

Stern PC, Dietz T, Kalof L. 1993. Value Orientations, Gender, and Environmental Concern. Environment and Behavior 25:322-348.

Stronza A. 2009. The economic promise of ecotourism for conservation. Journal of Ecotourism 6:210-221.

Sunderland T, Ehringhaus C, Campbell B. 2008. Conservation and development in tropical forest landscapes: a time to face the trade-offs? Environmental Conservation 34:276-279.

Svarstad H, Benjaminsen TA. 2017. Nothing succeeds like success narratives: a case of conservation and development in the time of REDD. Journal of Eastern African Studies 11:482-505.

Tilman D, Balzer C, Hill J, Befort BL. 2011. Global food demand and the sustainable intensification of agriculture. Proceedings of the National Academy of Sciences 108:20260-20264.

Tole L. 2010. Reforms from the Ground Up: A Review of Community-Based Forest Management in Tropical Developing Countries. Environmental Management 45:1312-1331. 
UNODC. 2011. The alternative development model in San Martín: A case study on local economic development. Oficina de las Naciones Unidas contra la Droga y el Delito (UNODC).

Valladares C, Boelens R. 2019. Mining for Mother Earth. Governmentalities, sacred waters and nature's rights in Ecuador. Geoforum 100:68-79.

Waylen KA, Fischer A, McGowan PJK, Thirgood SJ, Milner-Gulland EJ. 2010. Effect of Local Cultural Context on the Success of Community-Based Conservation Interventions. Conservation Biology 24:1119-1129.

West P, Igoe J, Brockington D. 2006. Parks and peoples: The social impact of protected areas. Annual Review of Anthropology 35:251-277.

Wilson EO. 2016. Half-Earth: Our Planet's Fight for Life. Liveright Publishing, London, UK.

Wunder S. 2013. When payments for environmental services will work for conservation. Conservation Letters 6:230-237.

Wyborn C. 2015. Co-productive governance: A relational framework for adaptive governance. Global Environmental Change 30:56-67.

Youdelis M. 2013. The competitive (dis)advantages of ecotourism in Northern Thailand. Geoforum 50:161-171.

Zinngrebe Y. 2016. Incorporating biodiversity conservation in Peruvian development: A history with different episodes. 1606, DARE Discussion Papers. Georg-August University of Göttingen, Department of Agricultural Economics and Rural Development (DARE). 